\title{
1. PALEOCEANOGRAPHY OF UPPER MAESTRICHTIAN TO EOCENE BENTHIC FORAMINIFERAL ASSEMBLAGES AT SITES 752, 753, AND 754, EASTERN INDIAN OCEAN ${ }^{1}$
}

\author{
Ritsuo Nomura $^{2}$
}

\begin{abstract}
Late Maestrichtian to late Eocene bathyal benthic foraminiferal faunas at Sites 752, 753, and 754 on Broken Ridge in the eastern Indian Ocean were analyzed as to their stratigraphic distribution of species to clarify the relation between faunal turnovers and paleoceanographic changes.

Based on Q-mode factor analysis, eight varimax assemblages were distinguished: the Stensioina beccariiformis assemblage in the upper Maestrichtian to upper Paleocene; the Cibicidoides hyphalus assemblage in the upper Maestrichtian; the Cibicidoides cf. pseudoperlucidus assemblage in the upper Paleocene; the Anomalinoides capitatus/danicus assemblage in the uppermost Paleocene to lower Eocene; the Cibicidoides subspiratus assemblage in the lower Eocene; the Nuttallides truempyi assemblage in the lower and middle Eocene; the Osangularia sp. 1-Hanzawaia ammophila assemblage in the upper Eocene; and the Lenticulina spp. assemblage in the uppermost Eocene, Oligocene, and lower Miocene. The presence of the Osangularia sp. 1-Hanzawaia ammophila assemblage is related to the shallowing episode on Broken Ridge (upper bathyal), as a result of the rifting event that occurred in the middle Eocene.

The most distinct faunal change (the disappearance of about $37 \%$ of the species) occurred between the $S$. beccariiformis assemblage and the A. capitatus/danicus assemblage, at the end of the upper Paleocene. A. capitatus/danicus, Lenticulina spp., and varied forms of Cibicidoides replaced the Velasco-type fauna at this time. The timing of this event is well correlated with the known age at South Atlantic sites (Thomas, 1990; Kennett and Stott, 1990; Katz and Miller, 1990). The primary cause of the extinction of the Stensioina beccariiformis assemblage is elusive, but may have resulted from the cessation of deep-water formation in the Antarctic (Katz and Miller, 1990), and subsequent arrival of warm saline deep water (Thomas, 1990; Kennett and Stott, 1990). Another possibility may be a weakened influence of high-salinity water formed at the low latitudes such as the Tethys Sea. The extinction event corresponds to the change from higher $\delta^{13} \mathrm{C}$ values in benthic foraminifers to lower ones. An interpretation of $\delta^{13} \mathrm{C}$ values is that the eastern Indian deep water, characterized by young and nutrient-depleted water, became old water which was devoid of a supply of new water during the latest Paleocene to early Eocene. Prior to this benthic event, signals of related faunal change were detected in the following short periods: early and late Paleocene, near the boundary of nannofossil Zone CP4, and Zone CP5 of the late Paleocene at Site 752.

Among common taxa in the upper Maestrichtian, only seven species disappeared or became extinct at the Cretaceous/Tertiary boundary at Site 752 . The benthic foraminiferal population did not change for up to $2 \mathrm{~m}$ above the boundary, in contrast to the rapid decrease of the planktonic foraminiferal population at the boundary. A decrease in the number of benthic foraminifers occurs after that level, corresponding to an interval of decreased numbers of planktonic foraminifers and higher abundance of volcanic ash. Reduced species diversity $\left(H^{\prime}\right)$ suggests a secondary effect attributable to the dissolution of foraminiferal tests. The different responses of planktonic and benthic foraminifers to the event just above the boundary suggest that the Cretaceous/Tertiary event was a surface event as also suggested by Thomas (1990a). In addition, a positive shift of $\delta^{13} \mathrm{C}$ in benthic foraminifers after the event indicates nutrient-depleted bottom water at Site 752.
\end{abstract}

\section{INTRODUCTION}

During Ocean Drilling Program (ODP) Leg 121, we recovered an upper Maestrichtian to lower Eocene section at Site 752 on the crest of Broken Ridge (1086 m present water depth) (Fig. 1). Recovery of this section provided an opportunity to study benthic foraminiferal faunal changes across the Cretaceous/Tertiary boundary and the faunal turnover near the Paleocene/Eocene boundary.

Previous studies suggest that deep-sea benthic foraminifers were little affected by the catastrophic event at the Cretaceous/Tertiary boundary (Douglas and Woodruff, 1981; Hsü, 1986; Culver, 1987; Thomas, 1989, 1990a). The percentage of foraminiferal disappearances at the end of the Cretaceous has been estimated variably by different workers (Beckmann, 1960; Beckmann et al., 1982; Webb, 1973; Dailey, 1983; Keller, 1988;

\footnotetext{
${ }^{1}$ Weissel, J., Peirce, J., Taylor, E., Alt, J., et al., 1991. Proc. ODP, Sci. Results, 121: College Station, TX (Ocean Drilling Program).

${ }^{2}$ Department of Earth Sciences, Faculty of Education, Shimane University, Matsue, 690 Japan.
}

Thomas, 1990a, 1990b), but little is known about the benthic foraminiferal extinction in the Indian Ocean. Keller (1988) and Thomas (1990a, 1990b) discussed the change of infaunal and epifaunal proportions in relation to oxygen variation and primary productivity, respectively. Faunal turnover at the Cretaceous/Tertiary boundary is suggested to be related to a low oxygen epoch (Hsü, 1986) and a secondary effect of the collapse of primary productivity (Sheehan and Hansen, 1986; Arthur et al., 1987; Thomas, 1990a).

Turnover near the Paleocene/Eocene boundary has been considered the most dramatic benthic foraminiferal event of the Cenozoic (Tjalsma and Lohmann, 1983; Tjalsma, 1976; Schnitker, 1979; Miller et al., 1987; Boltovskoy and Boltovskoy, 1989; Berggren and Miller, 1989; Thomas, 1990a, 1990b; Katz and Miller, 1990). Thomas (1990b) stated that the diversity dropped by $50 \%$ over a period of less than $25,000 \mathrm{yr}$ in the latest Paleocene and that more than $35 \%$ of species last appeared at that time. The "benthic event" (Tjalsma and Lohmann, 1983) has been recognized also in the Indian Ocean (Sigal, 1974; Vincent et al., 1974).

The late Paleocene to early Eocene stable isotopes are characterized by a marked change from higher $\delta^{13} \mathrm{C}$ values to lower ones in benthic foraminifers (Shackleton et al., 1984, 1985; Miller et 


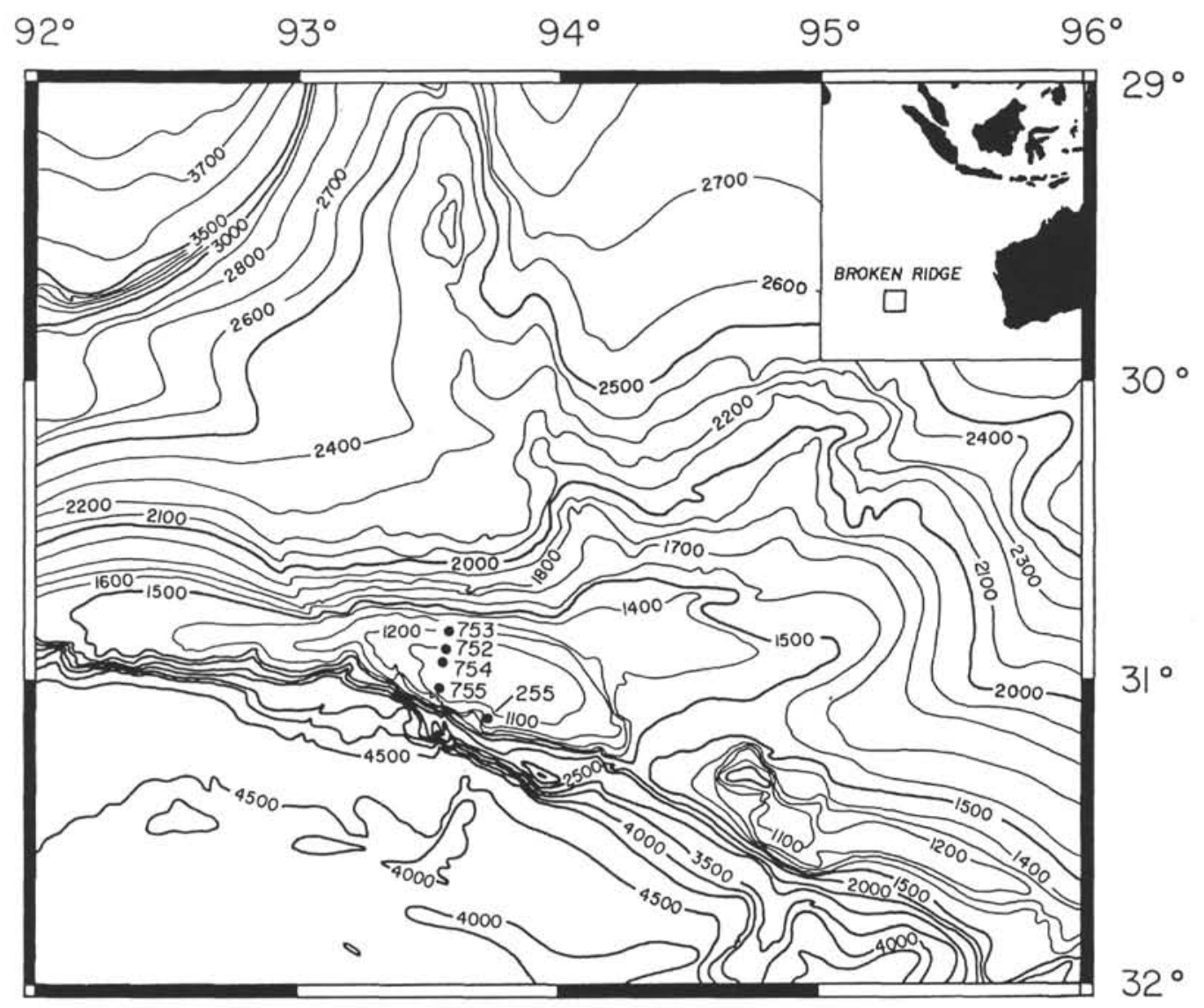

Figure 1. Location of ODP drilling sites on Broken Ridge. Site 755, where the Upper Cretaceous was recovered, is not incorporated in this study. Bathymetry in meters.

al., 1987; Katz and Miller, 1990; Kennett and Stott, 1990) and bulk carbonate (Shackleton and Hall, 1984; Shackleton et al., 1985). Benthic foraminiferal oxygen and carbon isotope changes apparently were coeval with the faunal turnover (Miller et al., 1987; Thomas, 1989, 1990a, 1990b; Katz and Miller, 1990; Kennett and Stott, 1990). The cause of the benthic foraminiferal extinction has recently been ascribed to changes in deep-water source regions (Miller et al., 1987; Thomas, 1990a, 1990b; Katz and Miller, 1990). Miller et al. (1987) and Katz and Miller (1990) stress the production of deep waters in the Antarctic during the late Paleocene, based on stable isotope analyses, and they considered that the extinction was caused by the cessation of the Antarctic deep-water formation, in agreement with Thomas (1990a, $1990 \mathrm{~b}$ ), who suggested that the deep waters were produced temporarily at low latitudes and reached the high latitudes because deep-water formation at high latitudes stopped, as proposed by Katz and Miller (1990) (hypothetical warm, saline deep water, Brass et al., 1982). The halothermal circulation characterized by warm, saline deep waters formed at low latitude (= the Tethys Sea) is referred to as the "Proteus Ocean" by Kennett and Stott (1990).

All of the above studies are based on fauna of the South Atlantic and Pacific oceans. Thus, detailed information on benthic foraminifers in the Indian Ocean can increase our understanding of how benthic foraminifers responded to these oceanographic changes. Because Broken Ridge Site 752 is situated between the Antarctic and the Tethyan region, it is particularly suited to the study of sources of deep waters. The purpose of this study is to clarify the stratigraphic distribution of benthic foraminiferal spe- cies and to discuss the middle to lower bathyal faunal events in relation to paleoceanography.

\section{MATERIAL AND METHODS}

Sites 752, 753, and 754 are located across the crest of Broken Ridge at present water depths of $1086 \mathrm{~m}, 1176 \mathrm{~m}$, and $1074 \mathrm{~m}$, respectively (Fig. 1). Paleogene and upper Maestrichtian samples were recovered from the prograding, downlapping carbonate sequence below an angular unconformity. At Site $752\left(30^{\circ} 53.475^{\prime} \mathrm{S}\right.$; $\left.93^{\circ} 34.625^{\prime} \mathrm{E}\right)$, Hole $752 \mathrm{~A}$ was cored with the advanced piston corer (APC) and extended core barrel (XCB) down to $308 \mathrm{mbsf}$ and Hole 752B was rotary-cored (RCB) to a total depth of 436 mbsf. Paleogene and upper Maestrichtian sediments are light green or gray nannofossil calcareous chalk with fine lamination and bioturbation. The lithology of the Cretaceous/Tertiary boundary is exceptional, with the intercalation of dark green volcanic ash layers (Rea et al,, 1990a) immediately above the boundary. The middle Eocene section at Site 753 (43.6-62.8 mbsf) was cored with the XCB. These sediments consist of white foraminifer-bearing nannofossil chalk. Upper Eocene brown nannofossil ooze was recovered from above the unconformity at Hole $754 \mathrm{~A}$ and only Core $121-754 \mathrm{~A}-14 \mathrm{X}$ is included in this study.

Upper Eocene Cores 121-752A-11H and -12H (Zone CP15a, -b) and 121-754A-14X (Zone CP15b), consisting of coarsegrained sediments with molluscan shell fragments, were also studied (Peirce, Weissel, et al., 1989; Rea et al., 1990a). In those cores, benthic foraminiferal fauna consist of lower neritic to upper bathyal species in association with small numbers of inner neritic 
species ( $<30 \mathrm{~mm}$ ) such as Amphistegina, Stomatorbina, and bryozoan shell fragments. In contrast with the well- to moderately preserved specimens of the outer neritic to upper bathyal fauna, however, the very badly preserved inner neritic specimens suggest downslope transport.

Samples were treated with a $3 \%$ hydrogen peroxide solution and washed through a $63-\mu \mathrm{m}$ sieve. Sample volume was measured by putting the sediments into a graduated cylinder with water before washing. Over 200 specimens per sample were picked from aliquots of the $>149-\mu \mathrm{m}$ size fraction that facilitates taxonomic works. This size fraction is the same as Nomura (this volume) and would be quantitatively comparable with Neogene faunas. Although deep-sea foraminifers have been studied by different size fraction ( $>63 \sim 300 \mu \mathrm{m}$; e.g., Kurihara and Kennett, 1985), earlier studies describing benthic foraminifers were based on a larger size fraction. The planktonic percentage is based on a count of over 100 individuals of both planktonic and benthic foraminifers.

Age estimates of samples are based on nannofossil biostratigraphy (Peirce, Weissel, et al., 1989; Pospichal et al., this volume) and magnetostratigraphy (Gee et al., this volume). The absolute ages are estimated by linear interpolation using sediment thickness and by the magnetic polarity time scale of Berggren et al. (1985).

In order to reduce species to a closely related species group (= assemblage), a Q-mode factor analysis (CABFAC; Klovan and Imbrie, 1971) with varimax rotation was applied to the relative abundance data. Taxa were included in this analysis if they occur at abundances $>4 \%$ in each sample and were found in more than two samples (Table 4). Several taxa that occur $>4 \%$ in Table 1 (back pocket) were not included because they were stratigraphically unimportant. The data set for the factor analysis is based on the composite faunal data from Sites 752 (upper Maestrichtian to lower Eocene and upper Eocene), 753 (middle Eocene), and 754 (upper Eocene). The faunal data from these sites represent different ages, except for the short overlap of the upper Eocene between Site 752 and Site 754. Thus, the results plotted and tabulated reveal the time-series faunal variation at Broken Ridge.

\section{RESULTS}

\section{Relative Abundance}

The stratigraphic distribution of benthic foraminifers at Sites 752,753 , and 754 is shown in Tables 1 (back pocket), 2, and 3, and the relative abundances of the most common species, plotted vs. depth below seafloor, are shown in Figure 2. The greatest change in relative abundances was near the Paleocene/Eocene boundary. Through the Maestrichtian and Paleocene, Stensioina beccariiformis attained $10 \%$ to $45 \%$, with an average of $25 \%$, but it became extinct in the upper part of Zone CP8 (Sample 121. $752 \mathrm{~A}-20 \mathrm{X}-1,70-75 \mathrm{~cm} ; 181.4 \mathrm{mbsf})$. A similar change of relative abundance and extinction is found in Pullenia coryelli $(3 \%-19 \%)$ and Cibicidoides hyphalus (0\%-21\%) in the Maestrichtian to the Paleocene. Cibicidoides cf. pseudoperlucidus occurs in Zones CP4 to CP8, with relative abundance of $4 \%-31 \%$, but decreases in relative abundance in Zone CP8 and became extinct in this zone.

The following three species are abundant in the lower Eocene: Alabamina dissonata (peak abundance 9\%), Bulimina tuxpamensis (peak abundance 15\%), Cibicidoides subspiratus (peak abundance 27\%), and Cibicidoides sp. 6 (peak abundance 5\%). Nuttallides truempyi occurs continuously through the Paleocene to the middle Eocene, except for seven upper Paleocene samples, but it does not occur in the upper Eocene samples. The extinction of $N$. truempyi has been attributed to bottom-water cooling during the middle to late Eocene (Corliss and Keigwin, 1986). Hanzawaia ammophila and Osangularia sp. 1, making up $13 \%$ and
Table 2. Occurrence of benthic foraminifers at Site 753.

\begin{tabular}{|c|c|c|c|c|}
\hline $\begin{array}{l}\text { Hole } \\
\text { Core, section } \\
\text { Interval }(\mathrm{cm})\end{array}$ & $\begin{array}{l}753 \mathrm{~A}- \\
6 \mathrm{H}-1 \\
70-75\end{array}$ & $\begin{array}{c}6 \mathrm{H}-5 \\
70-75\end{array}$ & $\begin{array}{c}7 \mathrm{H}-1 \\
70-75\end{array}$ & $\begin{array}{c}7 \mathrm{H}-5 \\
70-75\end{array}$ \\
\hline Alabamina dissonata & & 3 & 3 & \\
\hline Anomalinoides danicus & 2 & 7 & 19 & 10 \\
\hline Anomalinoides semicribratus & & & 5 & \\
\hline Anomalinoides spissiformis & 11 & 1 & 24 & 6 \\
\hline Astacolus spp. & 3 & & 3 & \\
\hline Bathysiphon sp. & & & & 1 \\
\hline Bulimina macilenta & 1 & & 1 & \\
\hline Bulimina trinitatensis & & & 1 & \\
\hline Cibicides lobatulus & & 1 & & \\
\hline Cibicidina walli & & 1 & & \\
\hline Cibicidoides $\mathrm{cf}$. alazanensis & 3 & 8 & 14 & 11 \\
\hline Cibicidoides cf. bradyi & & & 11 & 7 \\
\hline Cibicidoides sp. 12 & & 36 & 26 & \\
\hline Cibicidoides sp. 18 & 29 & 40 & 69 & 27 \\
\hline Cibicidoides spp. & 2 & 3 & 3 & 2 \\
\hline Clavulina sp. & & 4 & 3 & \\
\hline Dentalina colei & & & 3 & \\
\hline Dentalina multilineata & 2 & 1 & & \\
\hline Dentalina obliquata & 6 & 5 & & 1 \\
\hline Dentalina sp. & 1 & & 1 & \\
\hline Ellipsoidina abbreviata & & & & 1 \\
\hline Ellipsoidina $\mathrm{cf}$ abbreviata & & & 2 & \\
\hline Fissurina sp. & & 1 & & \\
\hline Gaudryina cf. laevigata & & & 1 & \\
\hline Guttulina problema & & 1 & & \\
\hline Gyroidina soldanii & 15 & 22 & 17 & 13 \\
\hline Gyroidina sp. 1 & & 4 & & \\
\hline Heronallenia sp. & & 1 & & \\
\hline Karreriella cf. subglabra & 1 & 1 & & 5 \\
\hline Lagena spp. & & 3 & & \\
\hline Lenticulina spp. & 14 & 13 & 39 & 25 \\
\hline Marginulina spp. & 2 & 1 & & \\
\hline Martinottiella sp. & & & & 1 \\
\hline Nodosarella sp. & 3 & & & \\
\hline Nodosarella subnodosa & & & 1 & 1 \\
\hline Nodosaria vertebralis & & & 2 & 1 \\
\hline Nodosaria spp. & 2 & 2 & & 1 \\
\hline Nonion havanensis & 1 & 2 & 4 & 1 \\
\hline Nonion sp. & & 1 & & \\
\hline Nuttallides truempyi & 30 & 34 & 94 & 31 \\
\hline Oolina spp. & 1 & & 2 & \\
\hline Oridorsalis umbonatus & 9 & 21 & 15 & 6 \\
\hline Osangularia mexicana & 3 & 6 & 8 & 5 \\
\hline Planulina costata & 26 & 36 & 1 & 17 \\
\hline Pleurostomella acuta & 2 & & & 3 \\
\hline Pleurostomella incrassata & & 4 & & \\
\hline Pleurostomella spp. & 3 & 1 & 4 & \\
\hline Pseudonodosaria sp. & & 1 & & \\
\hline Pullenia eocenica & 8 & 6 & & 1 \\
\hline Pullenia quadriloba & & 7 & 17 & 6 \\
\hline Pullenia subcarinata & & 4 & 1 & \\
\hline Pullenia sp. & 2 & & & \\
\hline Pyrulinoides sp. & 2 & & & \\
\hline Ramulina gloobulifera & 6 & 1 & & \\
\hline Saracenaria sp. & 1 & & & \\
\hline Sphaeroidina sp. & & 1 & & \\
\hline Spiroplectammina spectablis & & & & 4 \\
\hline Spiroplectammina sp. & 1 & & & \\
\hline Stilostomella aculeata & & & 2 & \\
\hline Stilostomella gracillima & 2 & 2 & 6 & \\
\hline Stilostomella subspinosa & 6 & 1 & 1 & 3 \\
\hline Textularia? sp. & & & 1 & \\
\hline Turrilina brevispira & 8 & 46 & 5 & 2 \\
\hline Uvigerina elongata & 1 & & & 3 \\
\hline Vaginulina mexicana & & & 3 & \\
\hline Vaginulina sp. & & & & 6 \\
\hline Vulvulina mexicana & & 1 & 3 & \\
\hline Total number of specimens & 209 & 330 & 419 & 201 \\
\hline
\end{tabular}


Table 3. Occurrence of benthic foraminifers at Site 754.

\begin{tabular}{|c|c|c|c|}
\hline $\begin{array}{l}\text { Hole } 754 \mathrm{~A} \\
\text { Core, section } \\
\text { Interval }(\mathrm{cm})\end{array}$ & $\begin{array}{l}14 X-1 \\
16-17\end{array}$ & $\begin{array}{l}14 X-1 \\
70-75\end{array}$ & $\begin{array}{l}14 X-3 \\
70-75\end{array}$ \\
\hline Alabamina dissonata & & & 5 \\
\hline Anomalinoides semicribratus & & & 2 \\
\hline Aragonia sp. & 2 & & \\
\hline Bulimina macilenta & 1 & 1 & 2 \\
\hline Bulimina trinitatensis & 1 & & 1 \\
\hline Bulimina tuxpamensis & 1 & & 2 \\
\hline Bulimina cf. tuxpamensis & & 2 & \\
\hline Bulimina sp. & & 3 & \\
\hline Cibicides cf. aknerianus & 2 & 9 & \\
\hline Cibicidina walli & & & 3 \\
\hline Cibicidoides bradyi & 11 & 14 & 1 \\
\hline Cibicidoides eocaenus & & 22 & 1 \\
\hline Cibicidoides subspiratus & 1 & & 23 \\
\hline Cibicidoides truncanus & 3 & 30 & 15 \\
\hline Cibicidoides sp. 1 & 2 & 28 & 19 \\
\hline Cibicidoides sp. 3 & 1 & 7 & \\
\hline Cibicidoides sp. & 7 & 8 & 11 \\
\hline Clavulina sp. & & 4 & \\
\hline Dentalina vertebralis & & 5 & \\
\hline Dentalina spp. & & 4 & 4 \\
\hline Fissurina sp. & 1 & I & \\
\hline Gaudryina? sp. & & & 1 \\
\hline Globocassidulina globosa & 7 & 8 & 8 \\
\hline Globocassidulina punctata & & & 3 \\
\hline Globocassidulina sp. 1 & 1 & 25 & \\
\hline Globocassidulina spp. & & 1 & \\
\hline Guttulina problema & 1 & $i$ & \\
\hline Gyrodina soldanii & 5 & 18 & 4 \\
\hline Hanzawaia sp. 1 & & & 15 \\
\hline Karreriella subglabra & 2 & 4 & \\
\hline Karreriella sp. & & & 4 \\
\hline Lagena spp. & 4 & 5 & 1 \\
\hline Lenticulina spp. & 10 & 68 & 23 \\
\hline Marginulina spp. & & 1 & 1 \\
\hline Melonis pompilioides & & & 3 \\
\hline Nodosarella subcompacta & & & 1 \\
\hline Nodosaria limbata & & 1 & \\
\hline Nodosaria spp. & 2 & 10 & \\
\hline Nonion havanensis & 8 & 9 & 2 \\
\hline Nonionella? sp. & 1 & & \\
\hline Oolina spp. & & 4 & 1 \\
\hline Oridorsalis umbonatus & 13 & 15 & 5 \\
\hline Orthomorphina antillea & 2 & 3 & \\
\hline $\begin{array}{l}\text { Orthomorphina challenge- } \\
\text { riana }\end{array}$ & 1 & & \\
\hline Osangularia sp. 1 & 6 & 27 & 26 \\
\hline Planulina costata & 9 & 19 & \\
\hline Planulina sp. 1 & & 6 & \\
\hline Planulina sp. & & & 1 \\
\hline Pleurostomella? sp. & 1 & & \\
\hline Polymorphina & 1 & 1 & \\
\hline Pullenia spp. & 6 & 1 & \\
\hline Pullenia eocenica & 2 & 1 & \\
\hline Pullenia eocenica (?) & & & 1 \\
\hline Pullenia quadriloba & & 11 & \\
\hline Ramulina globulifera & & 1 & \\
\hline Saracenaria spp. & & 2 & 2 \\
\hline Stilostomella aculeata & & 4 & \\
\hline Stilostomella gracillima & 5 & 13 & 4 \\
\hline Stilostomella modesta & & 1 & 1 \\
\hline Stilostomella subspinosa & 1 & & \\
\hline Trifarina wilcoxensis & & & 8 \\
\hline Trifarina sp. & & 7 & \\
\hline Uvigerina elongata & & & 7 \\
\hline Uvigerina resurgens & 42 & 128 & \\
\hline Uvigerina sp. 3 & & 10 & 3 \\
\hline Uvigerina sp. 4 & & & 2 \\
\hline Uvigerina spp. & 2 & 5 & 1 \\
\hline Vulvulina mexicana & 1 & & \\
\hline Vulvulina spinosa & & 3 & \\
\hline Total number of specimens & 170 & 581 & 255 \\
\hline
\end{tabular}

$12 \%$ of the total fauna, respectively, in the upper Eocene (CP15), occur in Samples 121-752A-11H-1, 70-75 cm, to $121-752 \mathrm{~A}-11 \mathrm{H}-$ $5,70-75 \mathrm{~cm}$, and Samples 121-752A-12X-1, 13-15 cm, to 121$752 \mathrm{~A}-12 \mathrm{X}-1,24-26 \mathrm{~cm}$. Cibicidina walli is similar to the two above-mentioned species in occurrence and its relative abundance. Hanzawaia ammophila and $C$. walli are considered as indicating shallower paleodepths (outer neritic to upper bathyal; van Morkhoven et al., 1986). The occurrence of these species corresponds to the rifting event at Broken Ridge, which had ended by the time of seafloor spreading in magnetic anomaly 18 (Peirce, Weissel, et al., 1989). Anomalinoides capitatus/danicus occurs from Zone CP1 to the middle Eocene at Site 752. Its relative abundance increases in the Paleocene and Eocene. Bulimina trinitatensis occurs in the Paleocene and Eocene, with several small peak abundances of less than $16 \%$. Oridorsalis umbonatus is commonly found in the Eocene, with a peak abundance of up to $33 \%$, but it is rare in the Paleocene samples despite its long range and cosmopolitan occurrence. Lenticulina spp. is represented throughout the section at Sites 752, 753, and 754 .

Gyroidinoides quadratus forms $1 \%-12 \%$ of the total fauna in the upper Maestrichtian, along with rare species such as Bolivinoides draco and Cibicidoides dayi. This last species appears within the Cretaceous nannofossil Zone CC25. Smaller-sized Globocassidulina globosa appears in the lower Eocene, with a relative abundance up to $11 \%$ of the assemblage. Uvigerina resurgens makes up $25 \%$ of the total fauna (Sample 121-754A$14 \mathrm{X}-1,16-17 \mathrm{~cm})$ in the upper Eocene.

\section{Stratigraphic Ranges of Selected Benthic Foraminifers}

During the last decade, a large number of biostratigraphic and systematic studies on deep-sea benthic foraminifers has revealed that the first and last occurrences of some bathyal and abyssal species may be useful in constructing a biostratigraphic zonation (Tjalsma and Lohmann, 1983; van Morkhoven et al., 1986). Based on the synthesis of previous reports, Berggren and Miller (1989) proposed four zones for Paleocene to Eocene bathyal species. In this section, the stratigraphic ranges of selected species at Sites 752,753 , and 754 are compared with the results of these workers (Fig. 3).

The last occurrence datum of Coryphostoma incrassata occurs in the short interval across the Cretaceous/Tertiary boundary that is defined by the last appearance of Cretaceous planktonic foraminifers and the first appearance of Tertiary nannofossils. Bolivinoides draco was not found in Sample 121-752B-11R-3, $112-114 \mathrm{~cm}$, just below the Cretaceous/Tertiary boundary. The extinction horizon of these species agrees with the results of van Morkhoven et al. (1986), who emphasized these forms as Late Cretaceous guide fossils. Cibicidoides dayi disappears in the upper Maestrichtian samples at Site 752, although its occurrence is recorded until planktonic foraminiferal P5 Zone by van Morkhoven et al. (1986) and Berggren and Miller's (1989) BB1. Tjalsma and Lohmann (1983) pointed out that many Paleocene species become extinct at the boundary between planktonic foraminiferal Zones P5 and P6a. Recently Thomas (1990a, 1990b) estimated that the latest Paleocene faunal turnover occurred at 57.5 $\mathrm{Ma}$ in the Aubry et al. (1988) time scale (middle of CP8). The extinctions of Stensioina beccariiformis, Coryphostoma midwayensis, Cibicidoides hyphalus, and Cibicidoides velascoensis occurred in the latest Zone CP8 at Site 752. The last occurrences of Osangularia velascoensis and Gyroidinoides globosus are in Zones CP4-CP5 at Site 752, which is somewhat earlier than the last appearance in planktonic foraminiferal Zones P5 and P6a (Tjalsma and Lohmann, 1983; van Morkhoven et al., 1986). This difference may be attributed to the rare and sporadic occurrences of these species in Paleocene samples, so that the species may have been missed in the examination of Broken Ridge samples. 

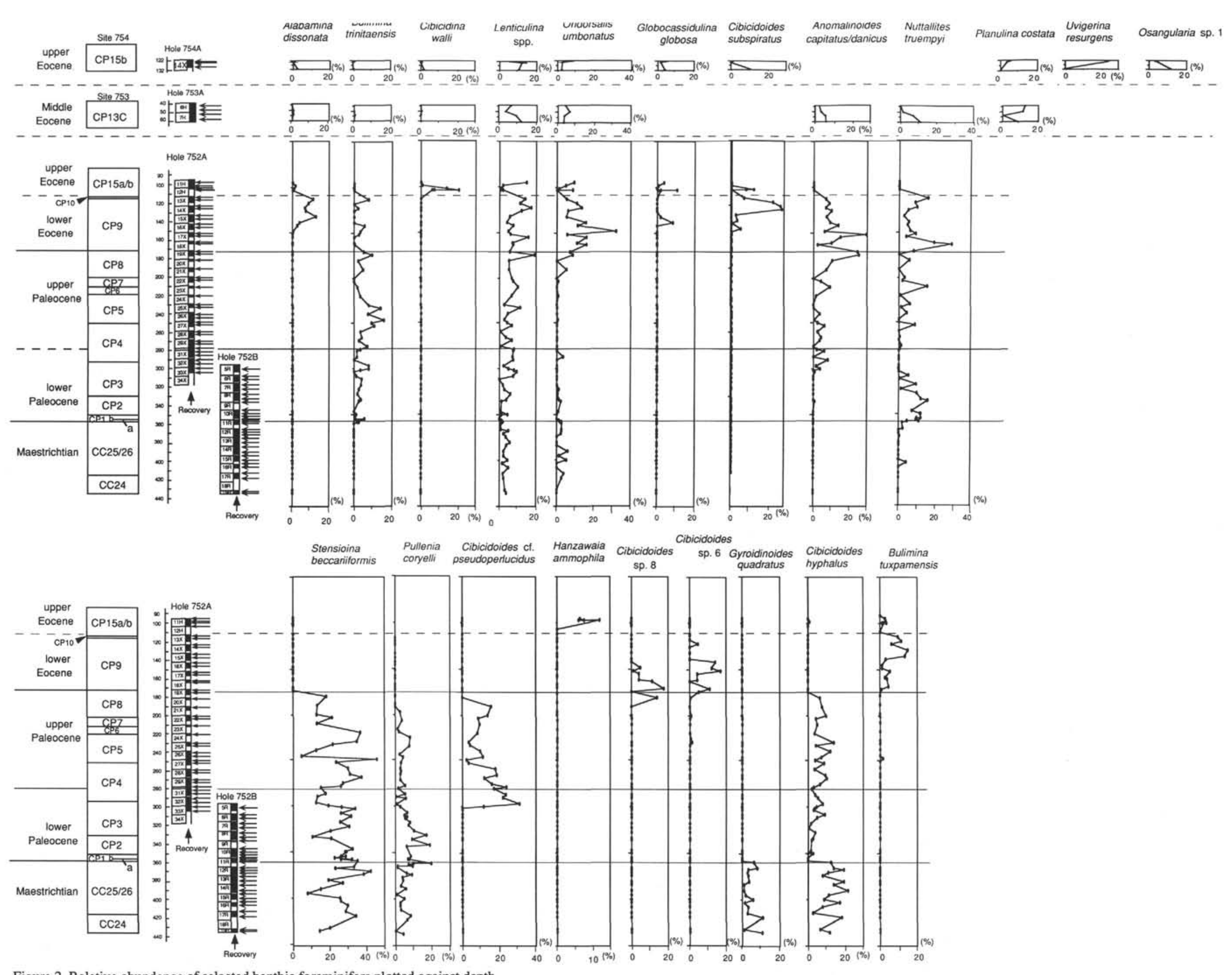


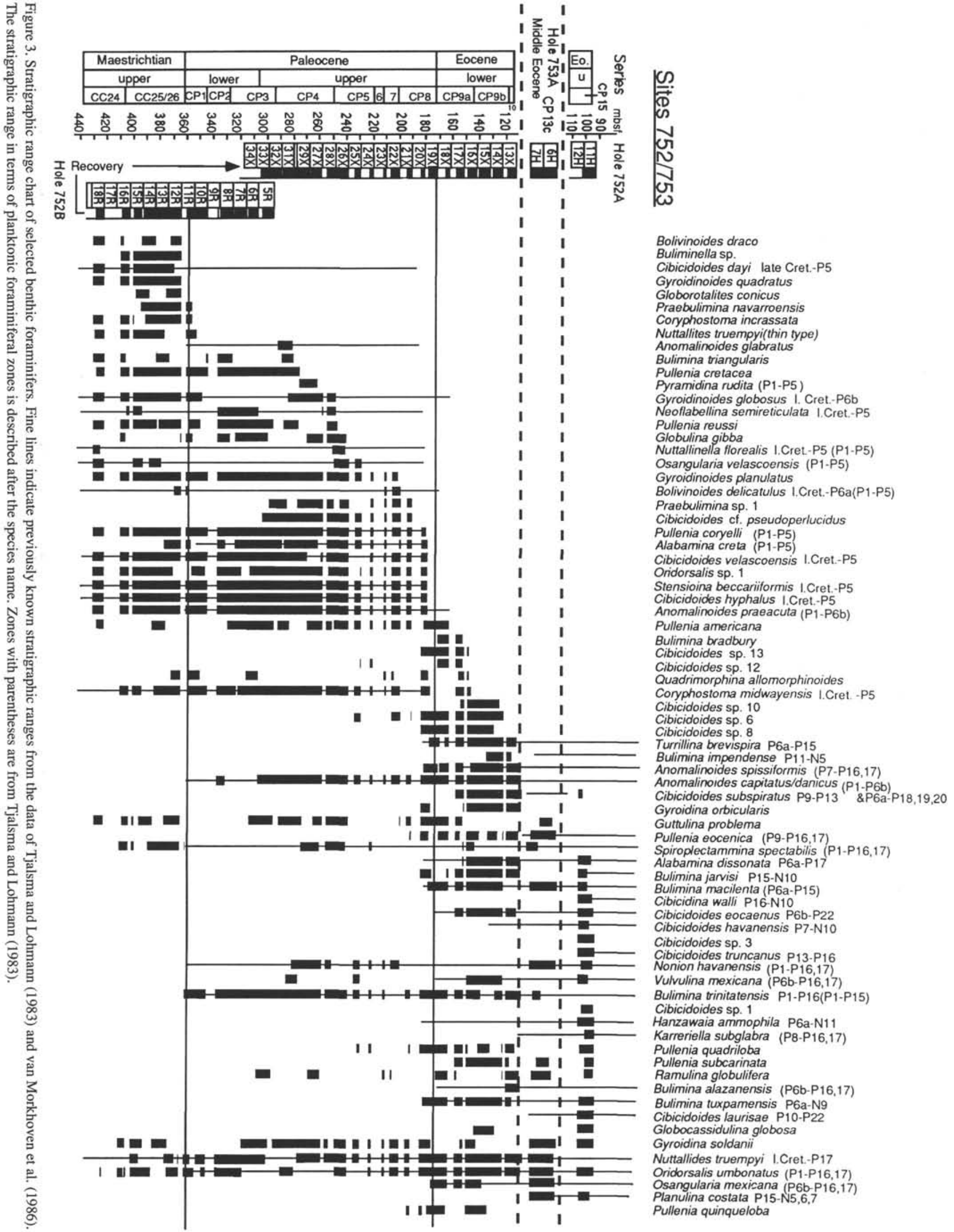


Turrilina brevispira first occurs in Sample 121-752A-18X-2, $67-70 \mathrm{~cm}$, which is assigned to the lower part of Zone CP9a, but its first appearance is known from Zone P6a (= Zone CP8b) (van Morkhoven et al., 1986). Cibicidoides subspiratus ranges from the uppermost lower Eocene (Zone P9) to the middle Eocene (Zone P13) (van Morkhoven et al., 1986; Zone BB3 of Berggren and Miller, 1989), but at Site 752 it occurs from the lowermost Eocene (Zone CP9a [ Zone P6b]). Pullenia eocenica occurs from the uppermost Paleocene (Zone CP8) to the lower Eocene at Site 752 and to the middle Eocene at Site 753. Tjalsma and Lohmann (1983) reported its first appearance in the lower Eocene (Zone P9 $(=\mathrm{CP} 11-12 \mathrm{a}))$. The first appearance of Bulimina macilenta is in the lowermost Eocene sample (121-752A-19X-1, 70-75 cm, CP9a), almost the same as the first appearance (P6a-P6b) determined by Tjalsma and Lohmann (1983). Alabamina dissonata ranges from lower Eocene (upper part of Zone CP9a) to upper Eocene (Zone CP15b) at Site 752, but van Morkhoven et al. (1986) records its first appearance from the Paleocene (P6a). Cibicidoides eocaenus is abundant in the lower Eocene at Site 752 ; its first occurrence is in Zone CP9a. Cibicidoides truncanus, known to have a rather short stratigraphic range useful as a biostratigraphic indicator (Zones P13-P16; van Morkhoven et al., 1986; Berggren and Miller, 1989), is found only in the upper Eocene Samples 121-752A-11 H-1, 70-75 cm, to 121-752A-11H$5,70-75 \mathrm{~cm}$ (95.4-101.4 mbsf; Zone CP15b). Hanzawaia ammophila is reported to have long range (uppermost Paleocene [Zone P6a] to middle Miocene [Zone N11]; van Morkhoven et al., 1986), but in the Broken Ridge cores, H. ammophila occurs only in upper Eocene samples immediately above the erosional unconformity (Zone CP15b). Globocassidulina punctata has been known from the Miocene (van Morkhoven et al., 1986), but rare specimens of this species occur from the upper Eocene (Sample 121-754A$14 \mathrm{X}-3,70-75 \mathrm{~cm}$; CP15b).

\section{Diversity}

The number of species per sample varies widely, probably in response to paleoenvironmental differences. In general, the species number per 100 specimens ranges from 10 to 20 , with an average of 15.22 in Maestrichtian to Paleocene samples. Lower Eocene samples show less variation, with about 10 species per 100 specimens (Fig. 4). The lowermost Eocene Sample 121$752 \mathrm{~A}-19 \mathrm{X}-1,70-75 \mathrm{~cm}$ (171.80 mbsf), has the lowest average number of species (5.7). This horizon is correlated with the interval just above the Paleocene/Eocene boundary event. By contrast, high numbers of species are found in the upper Eocene, which correspond to shallowing of Broken Ridge as a result of the rifting event (Peirce, Weissel, et al., 1989).

In order to evaluate faunal diversity and equitability, the Shannon-Wiener Information Function $\left(H^{\prime}\right)$ and $E\left(E=e^{H^{\prime}} /\right.$ the total number of species in a sample), respectively, were calculated (Fig. 5). Maestrichtian and Paleocene diversity values fall within the range of 3-4.5, and somewhat lower values are found near the Cretaceous/Tertiary boundary and in the upper part of nannofossil Zone CP4. Lower Eocene values are generally lower than Maestrichtian and Paleocene samples. Shannon-Wiener values of the middle Eocene at Site 753 and the upper Eocene at Sites 752 and 754 are much higher than those of older intervals, and exhibit less variation. The difference in diversity values between the lower and middle Eocene suggests paleoceanographic changes, and the values from the middle Eocene up to lower Miocene demonstrate a clear increase in faunal diversity.

Equitability (E), which is used as an index of the evenness of distribution of species among species, reveals no significant differences from upper Maestrichtian to upper Eocene. Sample 121-
$752 \mathrm{~B}-11 \mathrm{R}-1,44-47 \mathrm{~cm}$, in the ash layer above the Cretaceous/Tertiary boundary, which is characterized by somewhat badly preserved Stensioina beccariiformis and Nuttallides truempyi, shows an exceptionally high value, however, which may be partly due to dissolution of foraminiferal tests.

\section{Faunal Analysis}

The result of factor analysis shows that the first eight factors explain $82.5 \%$ of the faunal variation in the data set (Tables 4 and 5). These factors are here recognized as varimax assemblages, with characteristic stratigraphic distributions as shown in Figure 6 . Samples having factor loadings of $>0.5$ were used to represent various assemblages (Fig. 7).

Stensioina beccariiformis varimax assemblage (factor 1; $39.21 \%$ of the total variance) is characterized by the occurrence of $S$. beccariiformis in association with Pullenia coryelli, Nuttallides truempyi, and Cibicidoides velascoensis. This assemblage occurred in the upper Maestrichtian and Paleocene. The main constituents of this assemblage are included in the Velasco-type fauna of Berggren (1974) and Berggren and Aubert (1975). This assemblage is replaced by lower Eocene assemblages in Zone CP8 (between Samples 121-752A-19X-3, 75-79 cm, and 121-754A20X-1, 70-75 cm; 174.85-181.40 mbsf), just before the Paleocene/Eocene boundary. Distinctly reduced factor loadings are detected in upper Zone CP3 (Samples 121-752A-32X-5, 70-75 $\mathrm{cm}$, to 121-752A-32X-1, 70-75 cm) and lower Zone CP5 (Sample $121-752 \mathrm{~A}-26 \mathrm{X}-5,97-100 \mathrm{~cm})$.

Anomalinoides capitatus/danicus varimax assemblage (factor $2 ; 8.5 \%$ of the total variance) is characterized by Anomalinoides capitatus/danicus, Oridorsalis umbonatus, Cibicidoides sp. 6, and Cibicidoides sp 8. This assemblage ranges from the uppermost Paleocene to lower Eocene (Samples 121-752A-13X-1, 70$75 \mathrm{~cm}$, to $121-752 \mathrm{~A}-19 \mathrm{X}-3,75-79 \mathrm{~cm} ; 113.60-174.85 \mathrm{mbsf})$ and corresponds to a period of reduced species diversity.

Cibicidoides cf. pseudoperlucidus varimax assemblage (factor $3 ; 11.86 \%$ of the total variance) is characterized by Cibicidoides cf. pseudoperlucidus, Bulimina trinitatensis, and Cibicidoides hyphalus. This assemblage is intercalated in the Stensioina beccariiformis varimax assemblage in the upper Paleocene.

Osangularia sp. 1-Hanzawaia ammophila varimax assemblage (factor $4 ; 4.76 \%$ of the total variance) is recognized only in the upper Eocene samples $(121-752 \mathrm{~A}-11 \mathrm{H}-3,70-75 \mathrm{~cm}$, to $121-$ $752 \mathrm{~A}-12 \mathrm{X}-1,24-26 \mathrm{~cm})$. This assemblage is characterized by Osangularia sp. 1 and $H$. ammophila.

Nuttallides truempyi varimax assemblage (factor $5 ; 5.68 \%$ of the total variance) is dominated by $N$. truempyi and Cibicidoides sp. 18. This assemblage characterizes the middle Eocene fauna (Zone CP13c) at Site $753(121-753 \mathrm{~A}-6 \mathrm{H}-1,70-75 \mathrm{~cm}$, to $121-$ 753A-7H-5, 70-75 cm; 44.3-59.9 mbsf), although this assemblage is distributed in several horizons such as Zones CP2, CP7, and CP9-10 at Site 752 .

Lenticulina spp. varimax assemblage (factor $6 ; 4.33 \%$ of the total variance) is represented by Lenticulina spp., Uvigerina resurgens, and Osangularia umbonatus. This assemblage represents the upper Eocene, Oligocene, and lower Miocene faunas at Broken Ridge.

Cibicidoides hyphalus varimax assemblage (factor 7; $4.05 \%$ of the total variance) co-occurs with the Stensioina beccariiformis varimax assemblage in the upper Maestrichtian and is represented by Cibicidoides hyphalus, Gyroidinoides quadratus, and $N$. truempyi. The value of factor loadings drops across the Maestrichtian and Paleocene boundary, though the values are too small to be significant (Figs. 6 and 7). 


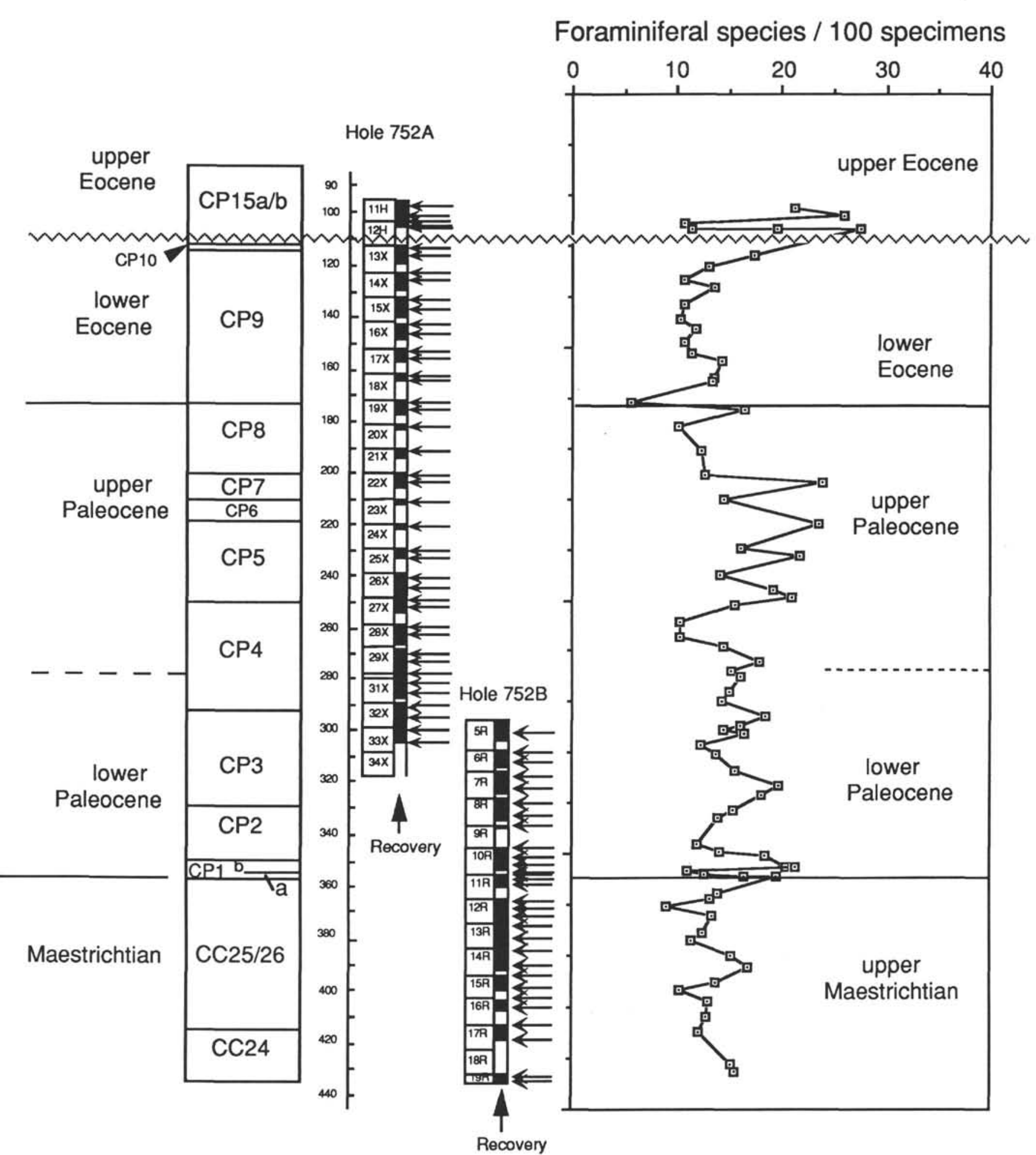

Figure 4. Number of species per 100 benthic foraminifer individuals at Site 752.

Cibicidoides subspiratus varimax assemblage (factor $8 ; 4.05 \%$ of the total variance) is in the middle lower Eocene (Samples 121-752A-13X-4, 62-67 cm, to 121-752A-15X-1, 70-75 cm; $118.02-133 \mathrm{mbsf}$ ). The main species of this assemblage are $C$. subspiratus, Alabamina dissonata, Lenticulina spp., and $\mathrm{Bu}$ limina tuxpamensis.

\section{Benthic Foraminiferal Occurrence Across the Cretaceous/Tertiary Boundary}

Benthic foraminifers present an important source of information on the deep-seafloor environment across the Cretaceous/Tertiary boundary. Among the common or rare taxa in the upper 


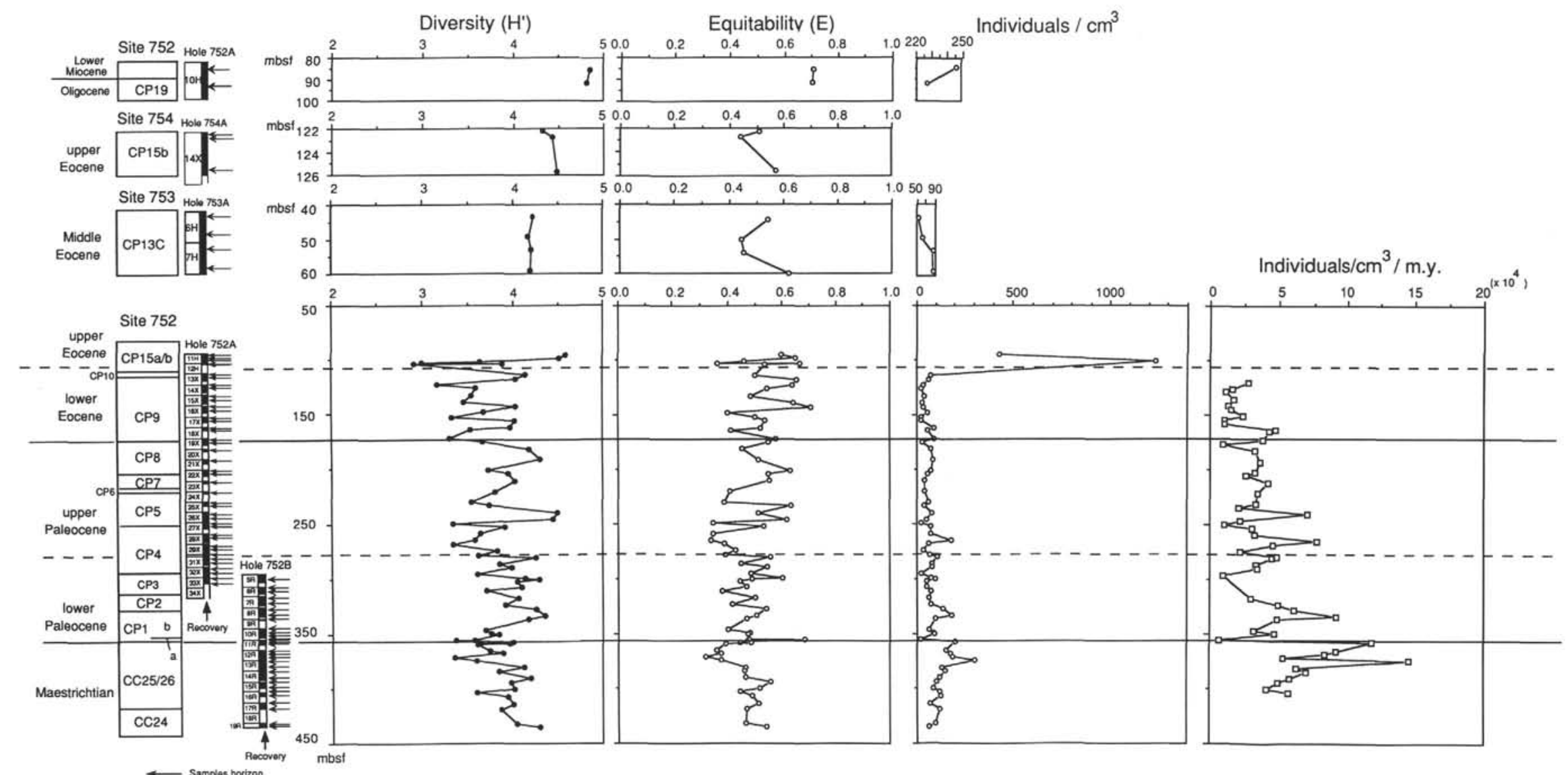

Figure 5. Benthic foraminiferal diversity, equitability, number of individuals per $\mathrm{cm}^{3}$, and number of individuals per million years. 
Table 4. Varimax factor loadings from factor analysis at Sites 752, 753, and 754.

\begin{tabular}{|c|c|c|c|c|c|c|c|c|c|}
\hline $\begin{array}{l}\text { Core, section, } \\
\text { interval }(\mathrm{cm})\end{array}$ & Communality & Factor 1 & Factor 2 & Factor 3 & Factor 4 & Factor 5 & Factor 6 & Factor 7 & Factor 8 \\
\hline \multicolumn{10}{|l|}{$121-754 \mathrm{~A}-$} \\
\hline $14 X-1,16-17$ & 0.4691 & 0.0286 & 0.0999 & -0.0154 & 0.0976 & 0.0398 & 0.6672 & -0.0187 & 0.0372 \\
\hline $14 X-1,70-75$ & 0.5648 & 0.0362 & 0.0856 & 0.0352 & 0.1583 & 0.0593 & 0.7251 & -0.0221 & -0.0110 \\
\hline $14 X-3,70-75$ & 0.6934 & 0.0193 & 0.0728 & 0.0602 & 0.5166 & 0.0409 & 0.4588 & 0.0193 & -0.4523 \\
\hline \multicolumn{10}{|l|}{$121-753 \mathrm{~A}-$} \\
\hline $6 \mathrm{H}-1,70-75$ & 0.8430 & 0.0634 & 0.1179 & 0.0164 & -0.0012 & 0.8807 & 0.2151 & 0.0331 & -0.0421 \\
\hline $6 \mathrm{H}-5,70-75$ & 0.6738 & 0.0311 & 0.1384 & 0.0117 & -0.0098 & 0.7792 & 0.2038 & 0.0663 & -0.0193 \\
\hline $7 \mathrm{H}-1,70-75$ & 0.8583 & 0.0939 & 0.2689 & 0.0154 & 0.0022 & 0.8707 & 0.0990 & -0.0338 & -0.0884 \\
\hline $7 \mathrm{H}-5,70-75$ & 0.6867 & 0.0062 & 0.2138 & 0.1248 & -0.0300 & 0.6607 & 0.4142 & 0.1017 & -0.0779 \\
\hline \multicolumn{10}{|l|}{$121-752 \mathrm{~A}-$} \\
\hline $10 \mathrm{H}-1,70-75$ & 0.5084 & 0.0362 & 0.1648 & 0.0604 & -0.0072 & 0.1954 & 0.6516 & 0.0180 & -0.1145 \\
\hline $10 \mathrm{H}-5,70-75$ & 0.3935 & 0.0330 & 0.0986 & 0.0308 & 0.0995 & 0.1394 & 0.5882 & -0.0179 & -0.0780 \\
\hline $11 \mathrm{H}-1,70-75$ & 0.7875 & 0.0352 & 0.3272 & 0.0950 & 0.0572 & 0.1803 & 0.7721 & 0.0856 & -0.1760 \\
\hline $11 \mathrm{H}-3,70-75$ & 0.5435 & 0.0054 & 0.1195 & -0.0098 & 0.6529 & 0.0202 & 0.3152 & 0.0519 & 0.0192 \\
\hline $11 \mathrm{H}-5,70-75$ & 0.7277 & -0.0099 & 0.0376 & 0.0100 & 0.8460 & 0.0398 & 0.0714 & 0.0210 & 0.0576 \\
\hline $12 X-1,5-7$ & 0.8929 & -0.0138 & -0.0252 & 0.0106 & 0.9434 & -0.0012 & -0.0035 & 0.0042 & -0.0450 \\
\hline $12 \mathrm{X}-1,13-15$ & 0.8537 & -0.0077 & -0.0116 & 0.0018 & 0.8332 & -0.0308 & 0.1003 & -0.0061 & -0.3850 \\
\hline $12 X-1,24-26$ & 0.8866 & -0.0115 & -0.0184 & 0.0125 & 0.9384 & -0.0049 & 0.0388 & 0.0028 & -0.0623 \\
\hline $13 X-1,70-75$ & 0.7224 & 0.1014 & 0.5063 & 0.1085 & 0.0415 & 0.4723 & 0.1446 & -0.0831 & -0.4374 \\
\hline $13 X-4,62-67$ & 0.8234 & 0.0459 & 0.5690 & 0.0382 & 0.0460 & 0.3438 & 0.2097 & 0.0305 & -0.5753 \\
\hline $14 X-1,70-75$ & 0.9400 & 0.0492 & 0.4858 & 0.0457 & 0.0982 & 0.2090 & 0.2190 & 0.0148 & -0.7733 \\
\hline $14 X-3,70-75$ & 0.9308 & 0.0162 & 0.3643 & 0.0631 & 0.1249 & 0.0905 & 0.1134 & 0.0161 & -0.8700 \\
\hline $15 X-1,70-75$ & 0.9087 & 0.0119 & 0.2547 & 0.0066 & 0.1322 & 0.0130 & 0.0225 & 0.0224 & -0.9083 \\
\hline $15 X-5,70-75$ & 0.4780 & 0.0236 & 0.5467 & -0.0288 & 0.0894 & 0.0868 & 0.1914 & 0.0283 & -0.3533 \\
\hline $16 \mathrm{X}-1,70-75$ & 0.7992 & 0.0101 & 0.8534 & 0.0976 & 0.0319 & 0.0777 & 0.1292 & 0.0209 & -0.1927 \\
\hline $16 \mathrm{X}-5,25-30$ & 0.6053 & 0.0255 & 0.7201 & -0.0224 & 0.0268 & 0.1350 & 0.2418 & 0.0787 & -0.0460 \\
\hline $17 X-1,70-75$ & 0.7726 & 0.0003 & 0.8591 & 0.1086 & 0.0362 & 0.0822 & -0.0625 & -0.0122 & -0.1033 \\
\hline $17 X-3,70-75$ & 0.8723 & 0.0139 & 0.8314 & 0.0896 & -0.0005 & 0.1649 & 0.3461 & 0.0818 & -0.1384 \\
\hline $18 X-1,71-75$ & 0.7287 & 0.0903 & 0.6769 & -0.0094 & 0.0295 & 0.5042 & 0.0249 & -0.0480 & -0.0644 \\
\hline $18 X-2,67-70$ & 0.7230 & 0.1319 & 0.5271 & -0.0743 & 0.0367 & 0.6386 & 0.0381 & -0.0671 & -0.0849 \\
\hline $19 X-1,70-75$ & 0.8169 & 0.0099 & 0.8897 & 0.0947 & 0.0325 & 0.1092 & -0.0552 & -0.0080 & 0.0138 \\
\hline $19 X-3,75-79$ & 0.7613 & -0.0097 & 0.7933 & 0.2289 & -0.0144 & 0.0253 & 0.2591 & 0.0354 & -0.1008 \\
\hline $20 X-1,70-75$ & 0.6941 & 0.6505 & 0.4293 & 0.2214 & 0.0289 & 0.0843 & -0.0324 & 0.1662 & 0.0311 \\
\hline $21 X-1,70-75$ & 0.9151 & 0.4645 & 0.2613 & 0.7707 & 0.0121 & 0.0381 & 0.0657 & 0.1729 & -0.0373 \\
\hline $22 X-1,70-75$ & 0.8516 & 0.4843 & 0.0268 & 0.7217 & 0.0088 & 0.1432 & 0.0606 & 0.2615 & -0.0524 \\
\hline $22 X-3,70-75$ & 0.9181 & 0.7706 & 0.1511 & 0.5231 & -0.0016 & 0.0136 & 0.1155 & 0.1054 & -0.0565 \\
\hline $23 X-1,54-56$ & 0.8486 & 0.5537 & 0.3523 & 0.4620 & 0.0181 & 0.4376 & -0.0134 & -0.0216 & -0.1097 \\
\hline $24 \mathrm{X}-1,70-73$ & 0.9525 & 0.8765 & 0.0398 & 0.4121 & 0.0000 & -0.0497 & 0.1013 & 0.0030 & -0.0137 \\
\hline $25 \times-1,79-84$ & 0.8703 & 0.8427 & 0.0601 & 0.3406 & 0.0112 & 0.0146 & -0.0162 & 0.1992 & 0.0123 \\
\hline $25 X-3,79-84$ & 0.7551 & 0.6997 & 0.1242 & 0.4679 & -0.0018 & 0.0117 & 0.1684 & 0.0083 & -0.0508 \\
\hline $26 \mathrm{X}-1,97-100$ & 0.9070 & 0.5334 & 0.1638 & 0.7007 & 0.0176 & 0.1398 & -0.0464 & 0.2862 & -0.0272 \\
\hline $26 X-5,97-100$ & 0.5973 & 0.1774 & 0.0953 & 0.7340 & 0.0218 & 0.0700 & -0.0033 & 0.1113 & 0.0154 \\
\hline $27 X-1,70-75$ & 0.8969 & 0.8894 & 0.0629 & 0.2865 & -0.0011 & -0.1286 & 0.0576 & -0.0018 & 0.0009 \\
\hline $27 \times-3,70-75$ & 0.8766 & 0.7845 & 0.2491 & 0.3996 & 0.0118 & 0.1471 & -0.0070 & 0.1280 & -0.0346 \\
\hline $28 X-1,70-75$ & 0.9260 & 0.7174 & -0.0063 & 0.6339 & 0.0046 & -0.0904 & -0.0150 & -0.0233 & 0.0226 \\
\hline $28 \times-5,70-75$ & 0.9569 & 0.7120 & 0.0456 & 0.6613 & 0.0069 & -0.0585 & -0.0074 & 0.0842 & 0.0028 \\
\hline $29 X-1,70-73$ & 0.9485 & 0.8074 & 0.0452 & 0.5145 & -0.0018 & -0.0817 & 0.0639 & 0.1375 & -0.0123 \\
\hline $29 X-5,70-73$ & 0.9439 & 0.7223 & -0.0311 & 0.6469 & 0.0120 & -0.0289 & -0.0267 & 0.0257 & 0.0214 \\
\hline $30 \times-1,73-76$ & 0.9167 & 0.5720 & 0.0190 & 0.7613 & -0.0040 & -0.0261 & 0.0830 & -0.0268 & -0.0339 \\
\hline $31 X-1,70-75$ & 0.8617 & 0.4888 & 0.1172 & 0.7729 & 0.0010 & 0.0320 & 0.0898 & -0.0139 & -0.0484 \\
\hline $31 X-5,70-75$ & 0.8849 & 0.4405 & 0.0000 & 0.8224 & -0.0009 & 0.0212 & 0.1112 & 0.0006 & -0.0407 \\
\hline $32 X-1,70-75$ & 0.8621 & 0.3364 & 0.1260 & 0.8516 & -0.0004 & 0.0280 & 0.0496 & 0.0468 & -0.0486 \\
\hline $32 X-5,70-75$ & 0.9121 & 0.2509 & -0.0208 & 0.9183 & 0.0144 & 0.0346 & -0.0640 & 0.0029 & -0.0005 \\
\hline $33 \times-1,68-71$ & 0.8593 & 0.6511 & 0.1109 & 0.6465 & 0.0048 & -0.0338 & 0.0324 & 0.0514 & -0.0177 \\
\hline $33 X-3,57-60$ & 0.8974 & 0.8987 & 0.0396 & 0.2295 & -0.0071 & -0.0643 & 0.1678 & 0.0429 & -0.0349 \\
\hline
\end{tabular}

Maestrichtian, only seven species such as Bolivinoides draco, Buliminella sp., Cibicidoides dayi, Gyroidinoides quadratus, Coryphostoma incrassata, Globorotalites conicus, and Praebulimina navarroensis last appear, or become extinct, between Samples 121-752B-13R-1, 40-43 cm, to 121-752B-11R-3, 64-66 $\mathrm{cm}$ (358.44-374.40 mbsf) (Fig. 3). The last appearance of Coryphostoma incrassata and Praebulimina navarroensis is $26 \mathrm{~cm}$ above the extinction horizon of the Cretaceous planktonic foraminifers such as Rugoglobigerina spp., Globigerinelloides spp., and globotruncanids, and $6 \mathrm{~cm}$ above the first appearance of the Tertiary nannofossil Biantholithus sparsus (Peirce, Weissel, et al., 1989). Among the disappearing species, only two (Bolivinoi- des draco and Coryphostoma incrassata) were suggested as becoming extinct at the Cretaceous/Tertiary boundary by van Morkhoven et al. (1983).

Of the 187 taxa that occur in the upper Maestrichtian to Paleocene, 23 taxa (including rare species) disappear at the end of the Maestrichtian. Thus, about $12.3 \%$ of the taxa disappeared at the Cretaceous/Tertiary boundary. Thomas (1990b) discussed last appearances of deep-sea benthic foraminifers at the Cretaceous/Tertiary boundary, and estimated that extinction rates fall usually in the range of $10 \%-25 \%$, in agreement with the $12.3 \%$ extinction at Site 752. Furthermore, minor changes in factor loadings reveal that the faunal turnover is slight across the Creta- 
Table 4 (continued).

\begin{tabular}{|c|c|c|c|c|c|c|c|c|c|}
\hline $\begin{array}{l}\text { Core, section, } \\
\text { interval }(\mathrm{cm})\end{array}$ & Communality & Factor 1 & Factor 2 & Factor 3 & Factor 4 & Factor 5 & Factor 6 & Factor 7 & Factor 8 \\
\hline \multicolumn{10}{|l|}{$121-752 \mathrm{~B}-$} \\
\hline $5 R-3,50-53$ & 0.8843 & 0.8806 & 0.0313 & 0.2784 & -0.0045 & -0.0453 & 0.1476 & 0.0718 & -0.0367 \\
\hline $6 \mathrm{R}-1,44-47$ & 0.9029 & 0.8867 & 0.0520 & 0.2552 & 0.0058 & 0.0955 & 0.0799 & 0.1770 & -0.0443 \\
\hline $6 \mathrm{R}-3,99-102$ & 0.8938 & 0.9177 & -0.0101 & 0.1842 & 0.0118 & -0.0662 & -0.0380 & 0.1070 & 0.0137 \\
\hline $7 \mathrm{R}-1,82-85$ & 0.9223 & 0.9288 & 0.0622 & 0.1564 & 0.0194 & 0.1554 & -0.0642 & -0.0491 & -0.0164 \\
\hline $7 \mathrm{R}-5,76-78$ & 0.8902 & 0.9226 & 0.0218 & 0.1791 & 0.0111 & -0.0344 & 0.0210 & -0.0689 & -0.0006 \\
\hline $8 \mathrm{R}-2,81-94$ & 0.9085 & 0.8946 & 0.0954 & 0.1693 & 0.0181 & 0.2539 & -0.0020 & 0.0375 & -0.0646 \\
\hline $8 R-6,101-104$ & 0.6769 & 0.6744 & 0.1209 & 0.0812 & 0.0388 & 0.4106 & -0.1057 & -0.1284 & -0.0560 \\
\hline $9 \mathrm{R}-1,42-45$ & 0.8645 & 0.8333 & 0.1392 & 0.0626 & 0.0313 & 0.3463 & -0.1253 & -0.0956 & -0.0328 \\
\hline $10 \mathrm{R}-1,105-108$ & 0.9445 & 0.9567 & 0.0207 & 0.1383 & 0.0156 & 0.0639 & -0.0462 & -0.0562 & -0.0035 \\
\hline $10 \mathrm{R}-3,112-115$ & 0.9560 & 0.9372 & 0.0714 & 0.1415 & 0.0141 & 0.1958 & -0.0132 & -0.1110 & -0.0386 \\
\hline $10 \mathrm{R}-4,79-81$ & 0.9389 & 0.9333 & 0.0520 & 0.1236 & 0.0229 & 0.1924 & -0.0790 & -0.0761 & -0.0137 \\
\hline 10R-CC & 0.8882 & 0.8932 & 0.0404 & 0.0669 & 0.0310 & 0.2211 & -0.1242 & -0.1372 & -0.0120 \\
\hline $11 \mathrm{R}-1,44-47$ & 0.8847 & 0.9135 & 0.0497 & 0.1276 & 0.0281 & 0.1452 & -0.0876 & -0.0430 & -0.0005 \\
\hline $11 \mathrm{R}-2,44-47$ & 0.8069 & 0.8581 & 0.0777 & 0.0767 & 0.0243 & 0.1893 & -0.0680 & -0.1316 & -0.0164 \\
\hline $11 \mathrm{R}-3,38-41$ & 0.8876 & 0.9183 & 0.0705 & 0.1254 & 0.0198 & 0.1337 & -0.0321 & -0.0653 & -0.0090 \\
\hline $11 \mathrm{R}-3,64-66$ & 0.7311 & 0.8416 & 0.0625 & 0.1236 & 0.0086 & 0.0374 & 0.0182 & -0.0399 & -0.0131 \\
\hline $11 \mathrm{R}-3,112-114$ & 0.9401 & 0.9013 & 0.0142 & 0.1921 & 0.0053 & -0.0699 & 0.0013 & 0.2926 & 0.0105 \\
\hline 12R-1, 104-107 & 0.9405 & 0.8939 & 0.0176 & 0.1744 & 0.0120 & -0.0370 & -0.0094 & 0.3303 & 0.0087 \\
\hline $12 \mathrm{R}-3,10-13$ & 0.9233 & 0.7857 & 0.0267 & 0.2366 & 0.0136 & 0.0026 & 0.0302 & 0.4977 & -0.0206 \\
\hline $12 \mathrm{R}-5,54-59$ & 0.9612 & 0.9306 & 0.0082 & 0.1970 & 0.0016 & -0.1089 & 0.0381 & 0.2070 & 0.0074 \\
\hline $13 \mathrm{R}-1,40-43$ & 0.9565 & 0.9385 & -0.0049 & 0.1830 & 0.0007 & -0.0952 & 0.0376 & 0.1779 & -0.0012 \\
\hline $13 \mathrm{R}-5,65-68$ & 0.9518 & 0.7133 & 0.0032 & 0.2360 & 0.0114 & 0.0085 & 0.0407 & 0.6202 & -0.0282 \\
\hline $14 \mathrm{R}-1,69-72$ & 0.9343 & 0.8546 & -0.0094 & 0.2012 & 0.0102 & -0.0420 & 0.0168 & 0.4015 & -0.0089 \\
\hline $14 \mathrm{R}-5,62-65$ & 0.8796 & 0.5678 & 0.0728 & 0.1926 & 0.0147 & 0.0153 & 0.0221 & 0.7167 & -0.0125 \\
\hline $15 \mathrm{R}-1,119-122$ & 0.4567 & 0.3967 & 0.0020 & 0.1204 & 0.0129 & 0.0578 & -0.0233 & 0.5294 & -0.0232 \\
\hline $15 \mathrm{R}-5,112-115$ & 0.9530 & 0.8774 & 0.0773 & 0.1975 & 0.0010 & -0.0589 & 0.1206 & 0.3458 & -0.0236 \\
\hline $16 \mathrm{R}-1,15-18$ & 0.8586 & 0.7712 & -0.0019 & 0.1845 & 0.0138 & 0.0423 & -0.0602 & 0.4734 & -0.0045 \\
\hline $16 \mathrm{R}-3,136-138$ & 0.9478 & 0.9090 & 0.0015 & 0.1919 & 0.0020 & -0.0687 & 0.0680 & 0.2738 & -0.0197 \\
\hline $17 \mathrm{R}-1,103-106$ & 0.8625 & 0.8997 & 0.0234 & 0.1572 & 0.0100 & -0.0406 & 0.0943 & 0.1310 & 0.0086 \\
\hline $17 \mathrm{R}-5,66-69$ & 0.9489 & 0.8494 & 0.0042 & 0.1994 & 0.0104 & -0.0536 & 0.0000 & 0.4297 & 0.0009 \\
\hline $19 \mathrm{R}-1,42-45$ & 0.6610 & 0.7248 & -0.0101 & 0.1780 & 0.0051 & -0.0403 & 0.0265 & 0.3183 & -0.0159 \\
\hline $19 R-3,49-52$ & 0.7797 & 0.6724 & -0.0113 & 0.1877 & 0.0099 & 0.0147 & 0.0184 & 0.5391 & -0.0313 \\
\hline Variance & & 39.209 & 8.505 & 11.861 & 4.756 & 5.682 & 4.334 & 4.047 & 4.05 \\
\hline Cumulative variance & & 39.209 & 47.714 & 59.575 & 64.332 & 70.014 & 74.348 & 78.395 & 82.445 \\
\hline
\end{tabular}

ceous/Tertiary boundary, although the Maestrichtian Cibicidoides hyphalus assemblage explains $4.05 \%$ of the original data set (Fig. 6). Results of this study, therefore, are in agreement with previously published results, that there was no major extinction event of benthic foraminifers at the Cretaceous/Tertiary boundary (Beckmann, 1960; Douglas and Woodruff, 1981; Hsü, 1986; Thomas, 1990a, 1990b).

The change in benthic foraminiferal number and planktonic percentage is shown in Figure $8 \mathrm{~A}$. The planktonic percentage shows a drastic decrease between Sample 121-752B-11R-3, 112$114 \mathrm{~cm}$ (358.92 mbsf), and 121-752B-11R-3, 64-66 cm (358.44 mbsf). The low planktonic percentage continues up to Sample $121-752 \mathrm{~B}-10 \mathrm{R}-\mathrm{CC}$ (354.8 mbsf), and increases up to $80 \%$ in Sample 121-752B-10R-4, 79-81 cm (351.65 mbsf), with some intervals of lower values (Samples 121-752B-10R-5, 124-127 $\mathrm{cm}$, to $121-752 \mathrm{~B}-10 \mathrm{R}-6,50-52 \mathrm{~cm} ; 352.34-353.10 \mathrm{mbsf})$. The total interval of these low planktonic percentages covers $6.1-6.8$ $\mathrm{m}$, although a small peak of planktonic percentage (40\%-50\%) does occur. The benthic foraminiferal number (expressed as the number of individuals $/ \mathrm{cm}^{3} / \mathrm{m}$.y.) decreases rapidly between Sample 121-752B-11R-2, 44-47 cm (356.74 mbsf), and Sample 121752B-11R-1, 44- $47 \mathrm{~cm}$ (355.24 mbsf), about $2 \mathrm{~m}$ above the boundary (corresponding to about $0.11 \mathrm{~m} . \mathrm{y}$.). The benthic foraminiferal number increases in Samples 121-752B-10R-7, 41-43 $\mathrm{cm}$, and 121-752B-10R-6, 100-102 cm (353.60-354.51 mbsf), and again decreases just above this interval.

The lower horizon is correlated with a dark green ash layer exhibiting a higher volume magnetic susceptibility variation that relates to ash content (Peirce, Weissel, et al., 1989; Rea et al., 1990a). The composite ash layer above the boundary spans from
352.65 to $358.17 \mathrm{mbsf}$ (Fig. 8B). The highest peaks of ash content (about 355-356 mbsf) correspond to the dramatically lower benthic foraminiferal number per million years. The benthic foraminifers in this interval have a very low species diversity and are badly preserved, with dissolved test walls. Therefore, some chemical effect on foraminifers from the ash layer may occur in this horizon. The influence of the ash layer is also detected in the decrease of carbon isotopic ratio in benthic foraminifers (Fig. 8C). The abrupt decrease of the benthic foraminiferal number/m.y. at about $2 \mathrm{~m}$ above the boundary is primarily related to the dissolution of foraminiferal fauna, but preservation of benthic foraminiferal tests is good to moderate in other horizons above the boundary.

\section{DISCUSSION}

\section{Cretaceous/Tertiary Boundary}

In contrast to the mass extinction of planktonic organisms, minor extinction of deep-sea benthic foraminifers at the Cretaceous/Tertiary boundary event has been documented in various studies as recently reviewed by Thomas (1990a).

Although the percentage of planktonic foraminifers decreases drastically just above the boundary, the benthic foraminiferal number per million years remained unchanged until about $2 \mathrm{~m}$ above the Cretaceous/Tertiary boundary at Broken Ridge. The reduced planktonic percentages continue to about $4.2 \mathrm{~m}$ above the boundary (within Zone CP1a). This interval falls within the low productivity horizon described in the "Broken Ridge Summary" chapter in Peirce, Weissel, et al. (1989). The reduced benthic foraminiferal number per million years, as well as the near-ab- 


\begin{tabular}{|c|c|c|c|}
\hline Stensioina beccariiformis & $\begin{array}{c}\text { Anomalina capitatus/ } \\
\text { A. danicus }\end{array}$ & $\begin{array}{l}\text { Cibicidoides cf. } \\
\text { pseudoperlucidus }\end{array}$ & $\begin{array}{l}\text { Osangularia sp. } 1 \text { - } \\
\text { Hanzawaia ammophila }\end{array}$ \\
\hline $\begin{array}{r}\text { Assemblge } \\
\text { (Factor 1) }\end{array}$ & $\begin{array}{l}\text { Assemblage } \\
\text { (Factor 2) }\end{array}$ & $\begin{array}{c}\text { pseudoperlucidus } \\
\text { Assemblage } \\
\text { (Factor 3) }\end{array}$ & $\begin{array}{l}\text { Assemblage } \\
\text { (Factor 4) }\end{array}$ \\
\hline
\end{tabular}
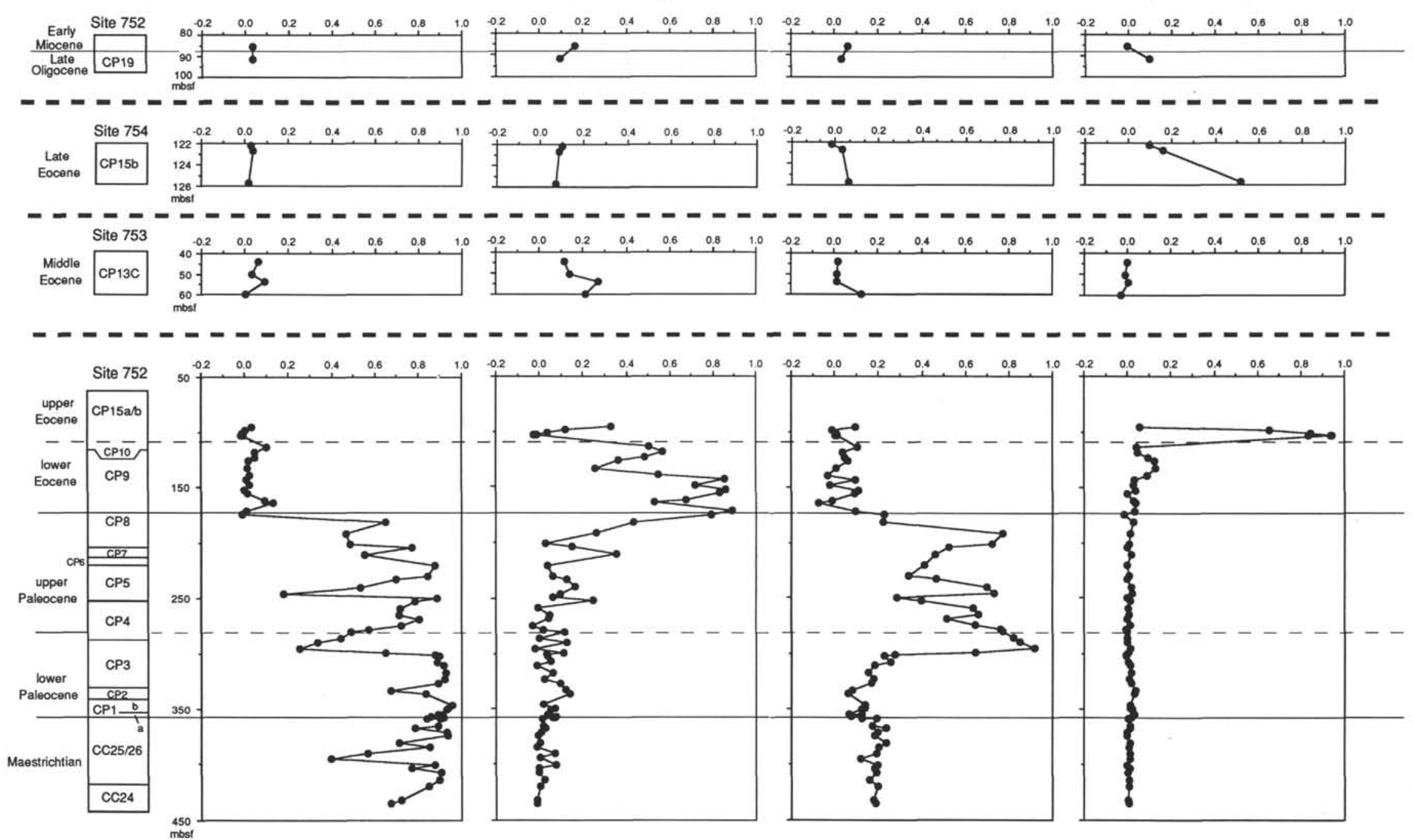


$\begin{array}{cccc}\text { Nuttallides truempyi } & \text { Lenticulina spp. } & \text { Cibicidoides hyphalus } & \text { Cibicidoides subspiratus } \\ \text { Assemblage } & \text { Assemblage } & \text { Assemblage } & \text { Assemblage } \\ \text { (Factor 5) } & \text { (Factor 6) } & \text { (Fag }\end{array}$

(Factor 5)

(Factor 7)

(Factor 8)

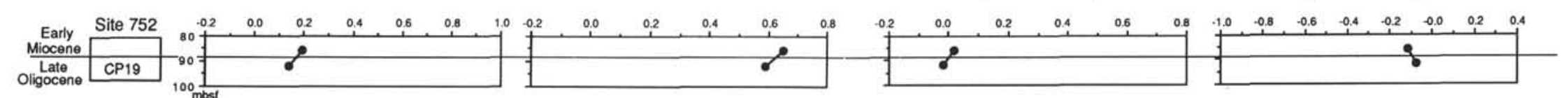

- - - - -

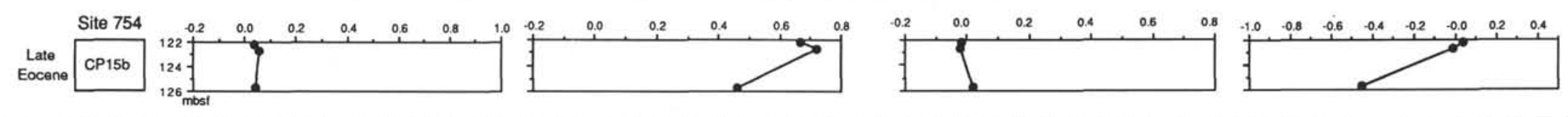

- - - - - - - - - - - - - - - - - - - - - - - - - - - - - - - - - - - - - - - - - - - - - -
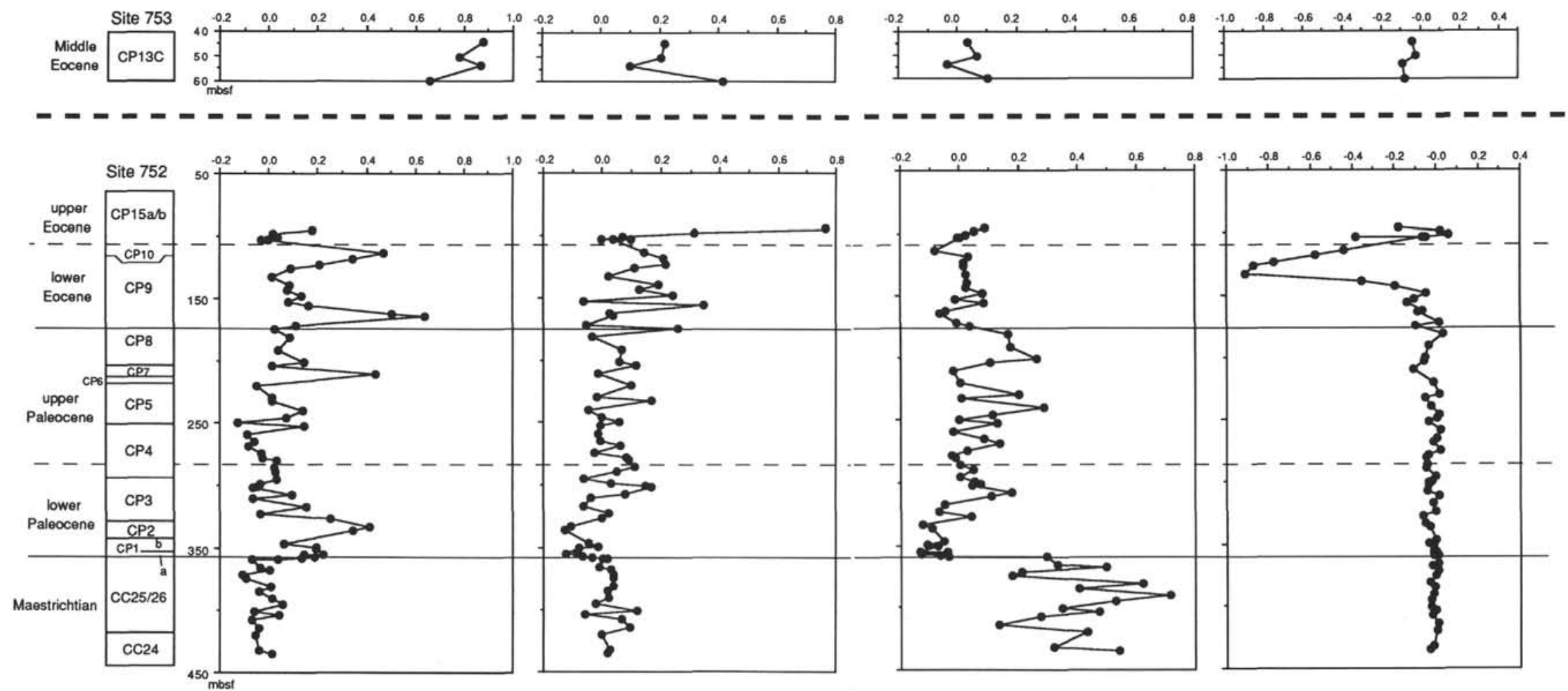

Figure 6. Varimax factor loadings plotted vs. depth and nannofossil zone. 
Table 5. Factor score matrix from varimax factor analysis.

\begin{tabular}{|c|c|c|c|c|c|c|c|c|}
\hline Taxa & Factor 1 & Factor 2 & Factor 3 & Factor 4 & Factor 5 & Factor 6 & Factor 7 & Factor 8 \\
\hline Alabamina creta & -0.048 & -0.005 & -0.027 & -0.003 & 0.006 & 0.002 & 0.092 & -0.005 \\
\hline Alabamina dissonata & -0.003 & 0.014 & -0.008 & -0.024 & 0.003 & -0.039 & -0.003 & -0.328 \\
\hline Ammosphaeroidina sp. & 0.014 & -0.012 & 0.050 & 0.003 & 0.024 & -0.016 & -0.043 & -0.005 \\
\hline Anomalina praeacuta & 0.118 & -0.026 & 0.104 & 0.005 & 0.019 & -0.022 & 0.026 & -0.005 \\
\hline Anomalinoides spissiformis & -0.010 & -0.004 & 0.001 & -0.001 & 0.111 & 0.006 & 0.022 & -0.041 \\
\hline Anomalinoides capitatus/danicus & -0.050 & 0.660 & 0.136 & -0.001 & -0.078 & -0.136 & 0.006 & 0.003 \\
\hline Anomalinoides semicribratus & -0.010 & 0.072 & 0.091 & 0.005 & 0.003 & -0.025 & 0.025 & 0.011 \\
\hline Bolivinoides draco & 0.001 & 0.000 & -0.008 & 0.001 & 0.004 & -0.005 & 0.073 & 0.001 \\
\hline Bulimina alazanensis & 0.001 & -0.007 & -0.002 & -0.011 & 0.004 & 0.047 & -0.005 & -0.002 \\
\hline Bulimina bradburyi & -0.001 & 0.036 & -0.006 & 0.003 & 0.013 & -0.005 & 0.001 & 0.020 \\
\hline Bulimina jarvisi & 0.004 & 0.034 & -0.007 & 0.016 & -0.015 & -0.012 & 0.009 & -0.021 \\
\hline Bulimina macilenta & 0.000 & 0.030 & -0.007 & 0.010 & -0.007 & 0.003 & 0.002 & -0.006 \\
\hline Bulimina trinitaensis & 0.018 & 0.153 & 0.231 & 0.015 & -0.008 & -0.055 & -0.110 & 0.043 \\
\hline Bulimina tuxpamensis & -0.002 & 0.108 & -0.030 & 0.055 & -0.044 & -0.017 & 0.007 & -0.29 \\
\hline Cibicidina walli & -0.008 & 0.008 & 0.008 & 0.363 & 0.015 & -0.058 & 0.010 & 0.07 \\
\hline Cibicidoides $\mathrm{cf}$. alazanensis & -0.009 & -0.027 & 0.007 & -0.007 & 0.093 & 0.023 & 0.022 & 0.011 \\
\hline Cibicidoides bradyi & 0.005 & -0.006 & -0.009 & -0.008 & -0.014 & 0.126 & -0.012 & 0.021 \\
\hline Cibicidoides eocaenus & 0.000 & 0.062 & -0.017 & 0.088 & -0.023 & 0.029 & -0.006 & -0.132 \\
\hline Cibicidoides mundulus & 0.005 & -0.023 & -0.007 & -0.025 & 0.002 & 0.166 & -0.016 & 0.01 \\
\hline Cibicidoides laurisae & 0.001 & 0.008 & -0.009 & 0.152 & -0.006 & 0.114 & -0.001 & 0.07 \\
\hline Cibicidoides praemundulus & 0.060 & -0.019 & 0.179 & 0.019 & 0.065 & -0.105 & 0.809 & 0.011 \\
\hline Cibicidoides $\mathrm{cf}$. pseudoperlucidus & -0.152 & -0.085 & 0.870 & 0.006 & 0.048 & -0.059 & -0.138 & -0.004 \\
\hline Cibicidoides subspiratus & -0.005 & -0.054 & -0.010 & 0.144 & -0.068 & -0.078 & -0.005 & -0.797 \\
\hline Cibicidoides truncanus & 0.002 & -0.009 & -0.007 & 0.145 & -0.013 & 0.128 & -0.008 & 0.038 \\
\hline Cibicidoides $\mathrm{cf}$. velascoensis & 0.155 & -0.015 & -0.068 & 0.014 & 0.067 & -0.073 & 0.181 & -0.027 \\
\hline Cibicidoides sp. 1 & 0.005 & -0.023 & -0.011 & 0.088 & -0.021 & 0.192 & -0.015 & 0.007 \\
\hline Cibicidoides sp. 6 & -0.011 & 0.346 & -0.020 & 0.018 & -0.106 & -0.055 & 0.009 & 0.107 \\
\hline Cibicidoides sp. 8 & 0.004 & 0.231 & -0.026 & 0.032 & -0.005 & -0.069 & 0.016 & 0.136 \\
\hline Cibicidoides sp. 10 & 0.001 & 0.076 & -0.016 & -0.002 & -0.039 & 0.002 & 0.002 & -0.032 \\
\hline Cibicidoides sp. 11 & -0.006 & 0.131 & -0.004 & 0.003 & -0.037 & -0.009 & 0.003 & 0.053 \\
\hline Cibicidoides sp. 12 & 0.000 & 0.071 & -0.014 & 0.011 & 0.055 & -0.031 & -0.001 & 0.045 \\
\hline Cibicidoides sp. 13 & -0.002 & 0.036 & 0.002 & -0.001 & -0.017 & 0.004 & 0.000 & 0.016 \\
\hline Cibicidoides sp. 18 & -0.036 & -0.121 & 0.024 & -0.018 & 0.430 & 0.062 & 0.090 & 0.047 \\
\hline Coryphostoma incrassata & 0.038 & -0.014 & -0.007 & 0.005 & 0.038 & -0.033 & 0.141 & -0.009 \\
\hline Dentalina spp. & 0.037 & -0.008 & -0.013 & 0.040 & 0.075 & 0.030 & 0.037 & 0.012 \\
\hline Gaudryina spp. & 0.013 & -0.011 & 0.084 & -0.003 & 0.006 & 0.004 & -0.046 & -0.009 \\
\hline Gavelinella sp. 1 & 0.107 & -0.004 & -0.073 & 0.019 & 0.075 & -0.056 & -0.168 & -0.002 \\
\hline Globocassidulina sp. 2 & 0.005 & -0.020 & -0.007 & -0.011 & 0.001 & 0.131 & -0.018 & 0.011 \\
\hline Globocasssidulina globosa & 0.009 & -0.033 & -0.019 & 0.085 & -0.028 & 0.244 & -0.030 & -0.059 \\
\hline Guttulina spp. & 0.010 & -0.017 & 0.102 & -0.003 & 0.019 & 0.012 & -0.030 & -0.002 \\
\hline Gyroidina orbicularis & 0.000 & 0.040 & -0.005 & -0.003 & -0.010 & -0.007 & 0.001 & -0.019 \\
\hline Gyroidina soldanii & -0.009 & -0.065 & 0.060 & 0.017 & 0.182 & 0.163 & 0.029 & 0.049 \\
\hline Gyroidinoides globosus & 0.019 & -0.008 & -0.020 & 0.001 & 0.008 & -0.011 & 0.144 & -0.004 \\
\hline Gyroidinoides plamulatus & 0.034 & -0.016 & 0.080 & -0.003 & -0.004 & 0.003 & 0.046 & -0.005 \\
\hline Gyroidinoides quadratus & 0.035 & -0.007 & -0.049 & -0.004 & -0.012 & 0.001 & 0.221 & -0.006 \\
\hline Hanzawaia ammophila & -0.009 & 0.009 & 0.006 & 0.513 & 0.010 & -0.039 & 0.011 & 0.096 \\
\hline Lenticulina spp. & 0.039 & 0.194 & 0.171 & -0.041 & 0.173 & 0.575 & 0.056 & -0.235 \\
\hline Nonion sp. & 0.031 & 0.001 & -0.007 & 0.005 & 0.026 & -0.021 & -0.048 & -0.004 \\
\hline Nonion havanensis & 0.005 & -0.006 & 0.004 & 0.000 & -0.011 & 0.069 & -0.010 & 0.011 \\
\hline Nuttallides truempyi (thin type) & 0.019 & -0.006 & -0.034 & 0.000 & 0.008 & -0.008 & 0.189 & -0.003 \\
\hline Nuttallides truempyi & 0.157 & 0.196 & -0.093 & 0.033 & 0.727 & -0.230 & -0.176 & -0.063 \\
\hline Oridorsalis sp. 1 & 0.028 & -0.005 & 0.047 & 0.000 & -0.001 & -0.002 & 0.095 & 0.003 \\
\hline Oridorsalis umbonatus & 0.008 & 0.433 & -0.080 & 0.001 & 0.045 & 0.279 & 0.112 & -0.033 \\
\hline Osangularia mexicana & -0.004 & 0.036 & -0.010 & -0.015 & 0.054 & 0.105 & 0.007 & 0.042 \\
\hline Osangularia sp. 1 & -0.008 & -0.034 & 0.007 & 0.709 & -0.005 & 0.044 & -0.006 & 0.048 \\
\hline Planulina renzi & 0.002 & -0.010 & -0.003 & -0.012 & 0.002 & 0.069 & -0.007 & 0.003 \\
\hline Planulina costata & -0.019 & -0.086 & 0.010 & -0.015 & 0.248 & 0.126 & 0.051 & 0.051 \\
\hline Pullenia coryelli & 0.237 & -0.021 & -0.004 & 0.028 & 0.113 & -0.086 & -0.155 & -0.004 \\
\hline Pullenia quadriloba & -0.006 & 0.019 & -0.002 & -0.004 & 0.067 & 0.038 & 0.013 & 0.016 \\
\hline Pullenia quinqueloba & 0.000 & 0.041 & -0.004 & -0.006 & -0.014 & 0.029 & -0.004 & 0.010 \\
\hline Stensioina beccariiformis & 0.908 & -0.012 & 0.153 & -0.005 & -0.162 & 0.039 & -0.032 & 0.024 \\
\hline Stilostomella gracillima & 0.002 & -0.022 & 0.007 & -0.002 & 0.023 & 0.202 & -0.021 & 0.023 \\
\hline Turrilina brevispira & -0.015 & -0.034 & 0.003 & -0.014 & 0.169 & 0.018 & 0.044 & -0.024 \\
\hline Uvigerina resurgens & 0.022 & -0.026 & -0.032 & -0.005 & -0.052 & 0.398 & -0.067 & 0.107 \\
\hline
\end{tabular}

sence of planktonic foraminifers in this interval, is considered to result from dissolution of foraminiferal tests. The differential response of benthic and planktonic foraminifers, however, within $2 \mathrm{~m}$ above the Cretaceous/Tertiary boundary probably means that the Cretaceous/Tertiary event occurred in the surface ocean (e.g., Thomas, 1990a, 1990b). The disappearance of some species such as Coryphostoma incrassata and Praebulimina navarroensis may be related to the collapse of the detritus-feeding food chain, as proposed by Sheehan and Hansen (1986), Arthur et al. (1987), and
Thomas (1990a, 1990b). Arthur et al. (1987) suggested that the rapid decrease of marine primary productivity resulted in selective elimination of organisms dependent on the flux of organic matter as a food source, so detritus and deposit feeders utilizing the organic matter stored within the sediments show fewer extinctions after the Cretaceous/Tertiary event.

The $\delta^{13} \mathrm{C}$ values of Stensioina beccariiformis increased slightly at 356.74-358.44 mbsf (Seto et al., this volume; Fig. 8C). In general, the benthic $\delta^{13} \mathrm{C}$ does not show the significant negative 


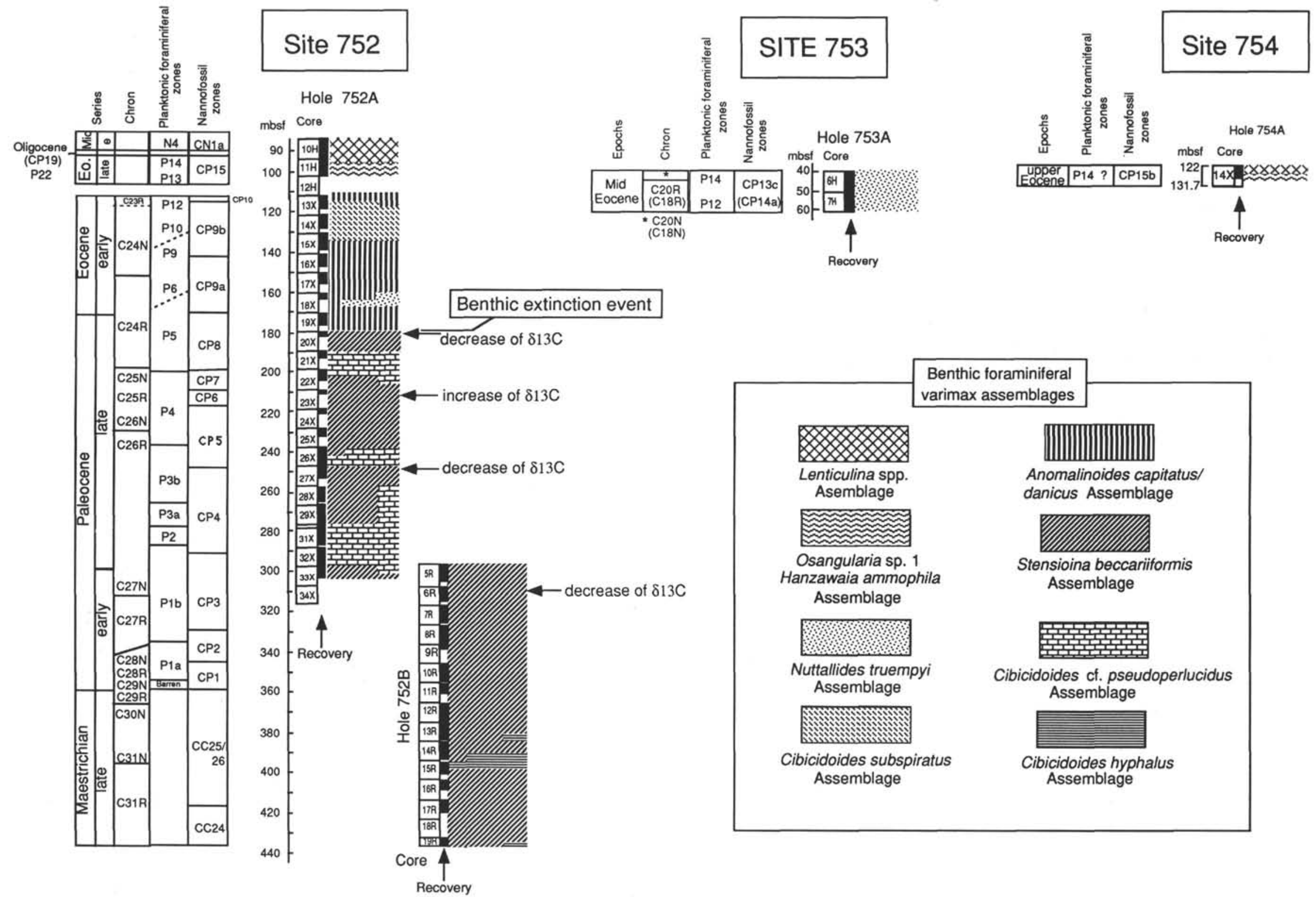

Figure 7. Stratigraphic distribution of varimax assemblages having factor loadings $>0.5$. 


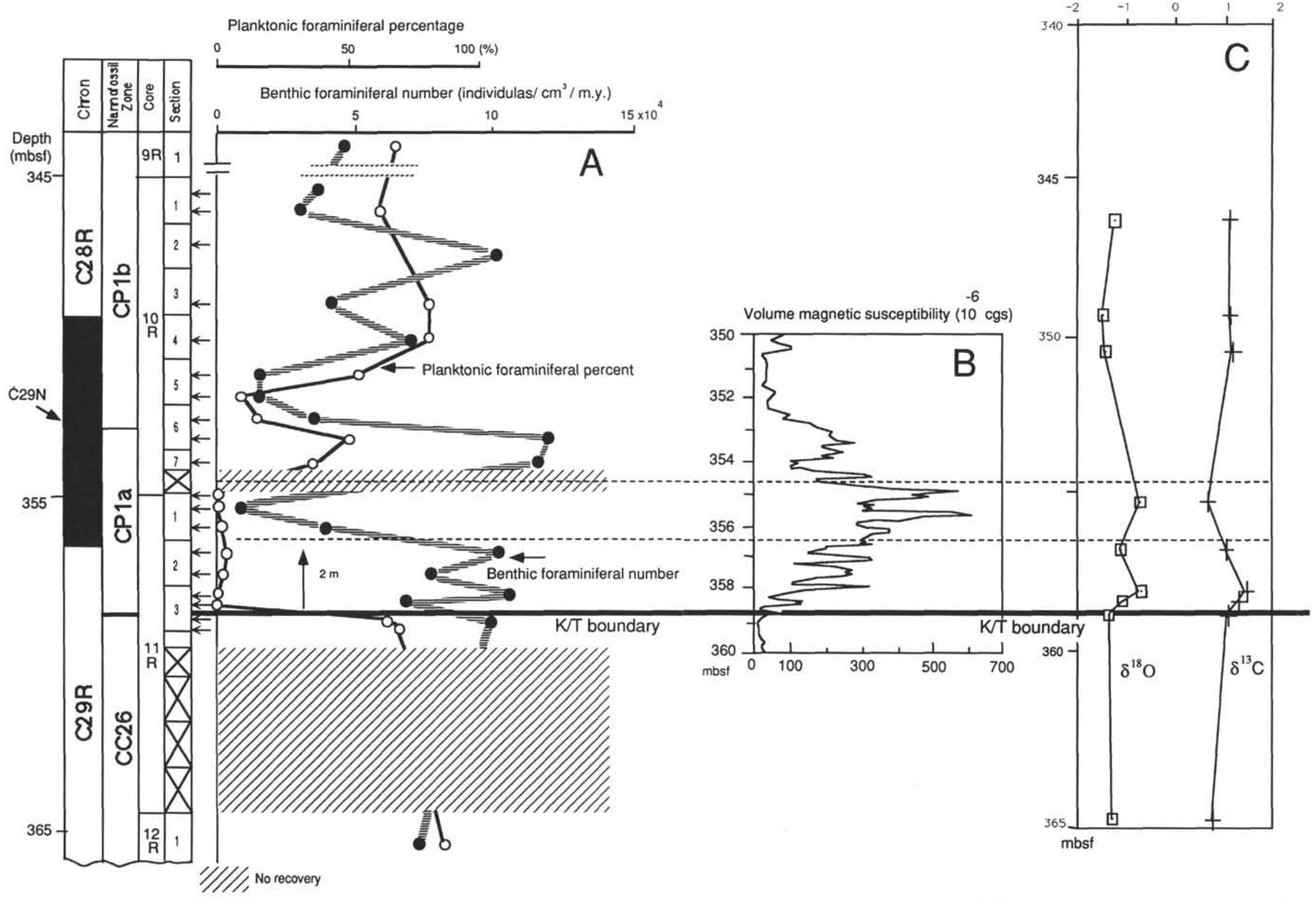

Figure 8. Close-up of the Cretaceous/Tertiary boundary. A. Planktonic foraminiferal percentages and benthic foraminiferal number per million years. B. Volume magnetic susceptibility. The interval between the two dashed lines has a high ash content. C. Oxygen and cargon isotope record based on analysis of 10 individuals of Stensioina beccariiformis (Seto et al., this volume). 
excursion of $\delta^{13} \mathrm{C}$ of planktonic foraminifers (Boersma and Shackleton, 1981; Boersma, 1984; Arthur et al., 1987; Keller, 1989). The positive shift of $\delta^{13} \mathrm{C}$ after the Cretaceous/Tertiary boundary event supports the theory of collapse of surface productivity, although the increased values are slight and vary between foraminiferal samples. This may indicate a reduced supply of organic matter to the seafloor environment at Broken Ridge as suggested by Keller (1989). Thomas (1990a, 1990b) reported that epifaunal species at Antarctic Sites 689 and 690 increased just above the Cretaceous/Tertiary boundary, probably as a result of the collapse of surface productivity. The epifaunal species dominate when there is a low amount of organic carbon (Corliss and Chen, 1988). Epifaunal species were not counted in this study, but highly oxygenated bottom water, as well as a low concentration of nutrients just after the Cretaceous/Tertiary event, agrees with the positive shift in $\delta^{13} \mathrm{C}$. Hsü (1986) suggested that bottom water was oxygen-deficient after the Cretaceous/Tertiary boundary event, but there is no evidence of such anoxic waters at the Broken Ridge or Maud Rise sites. The decrease of $\delta^{13} \mathrm{C}$ in Sample 121$752 \mathrm{~B}-11 \mathrm{R}-1,44-47 \mathrm{~cm}$, is correlated with the lowest values of both benthic foraminifers and planktonic foraminiferal percentages. The low value of $\delta^{13} \mathrm{C}$ in this interval is correlated with higher amount of ash and may be accounted for by a supply of ${ }^{12} \mathrm{C}$ from volcanic ash. It seems clear that surface productivity did not cause the negative shift of $\delta^{13} \mathrm{C}$.

\section{The Late Paleocene Benthic Extinction Event}

It remains unclear what caused the extinction of many Paleocene taxa, represented by the Stensioina beccariiformis assemblage. The Paleocene and Eocene climate is generally considered to have been warm and stable (Savin, 1977; Oberhänsli and Hsü, 1986), and thermal gradients between low and high latitude were considerably lower than those of today (e.g., Barron, 1987). The exact timing of disappearance varies with species, but the extinction event culminated at the end of the Paleocene and most affected shallower deep-sea taxa (Tjalsma and Lohmann, 1983). According to Thomas (1990b), more than $35 \%$ of the Antarctic region species disappeared during the latest Paleocene extinction event that occurred for a short period (about $350,000 \mathrm{yr}$ ). At Site 752 , about $36.6 \%$ of all Paleocene taxa (including rare taxa) disappeared at the end of the Paleocene. Although the paleodepth of Site 752 is slightly shallower than that of the Antarctic sites, the percentage of species that became extinct is similar.

Oberhänsli et al. (1984) and Oberhänsli and Hsü (1986) noted that the late Paleocene positive $\delta^{13} \mathrm{C}$ event in surface and bottom waters is related to the benthic faunal turnover. Miller et al. (1987), Thomas (1989), and Katz and Miller (1990) pointed out the correspondence between benthic extinction and bottom-water temperature increase in the late Paleocene. Deep water warmed about $4^{\circ} \mathrm{C}$ across the Paleocene/Eocene boundary, and minimum deep-water temperatures were $12^{\circ} \mathrm{C}$ at that time (Katz and Miller, 1990 ) and ranged up to $17^{\circ} \mathrm{C}$ (Kennett and Stott, 1990). At Site 752 , the bottom-water temperature variation during the Paleocene was small, and the early Eocene temperature was warm, with "spikes" of low benthic $\delta^{18} \mathrm{O}$ (Seto et al., this volume; Fig. 9). The Paleocene and lower Eocene $\delta^{18} \mathrm{O}$ record from Site 752 is similar to previously described records (Shackleton et al., 1984, 1985; Oberhänsli and Hsü, 1986; Miller et al., 1987; Kennett and Stott, 1990; Katz and Miller, 1990). A detailed examination, however, reveals that the benthic extinction event does not directly correlate with the change in $\delta^{18} \mathrm{O}$ variation (Fig. 9), but is more closely related to the changes in $\delta^{13} \mathrm{C}$, as demonstrated by Thomas (1989).

Low factor loadings for the Stensioina beccariiformis assemblage are closely correlated with the lowering of benthic $\delta^{13} \mathrm{C}$ values in upper Zone CP3 (Chron C25N), lower Zone (upper Zone C24R), and upper Zone CP8 (Chron C24R), respectively, al- though the changes in the $S$. beccariiformis assemblage were slightly later than the drop of $\delta^{13} \mathrm{C}$ (Fig. 9). The interval of high benthic $\delta^{13} \mathrm{C}$ in the upper Paleocene is coeval with other reported events in the South Atlantic, Pacific, and Antarctic oceans (Shackleton et al., 1984; Shackleton and Hall, 1984; Miller et al., 1987; Kennett and Stott, 1990; Katz and Miller, 1990). Thus, the Indian Ocean stable isotopic results support the conclusion that the late Paleocene oceanographic change occurred globally (Rea et al., 1990 b). Kroopnick (1985) showed that $\delta^{13} \mathrm{C}$ is controlled mainly by the input of organically produced carbon and subsequent oxidation. Therefore, oxygen-deficient waters show lower $\delta^{13} \mathrm{C}$ values (Miller and Fairbanks, 1985; Shackleton, 1986). Woodruff and Savin (1989) commented that low $\delta^{13} \mathrm{C}$ is related to aged oceanic water. In addition, the late Paleocene decrease in the surface-to-bottom $\delta^{13} \mathrm{C}$ gradient of the Pacific and the South Atlantic oceans was related to a decrease of surface ocean productivity (Shackleton et al., 1984, 1985; Shackleton and Hall, 1984; and Miller et al., 1987). Following these authors' results, the young, nutrient-depleted water developed not only in the middle to lower bathyal waters of the Indian Ocean, but also developed globally in the late Paleocene (CP7-8), and aged, oxygen-depleted water developed in the latest Paleocene and early Eocene. Miller et al. (1987) pointed out three potential source regions of nutrient-depleted bottom waters: the Antarctic region, the North Atlantic/Arctic region, and the Tethys region. In the discussion of faunal change in the Cape Basin, Pacific Ocean Site 577, and the Atlantic sector of the Southern Ocean, Miller et al. (1987) and Katz and Miller (1990) decided that oxygen and carbon isotopic records from the late Paleocene reflect the presence of Antarcticsource bottom water. They further suggested that the short-time elimination of Antarctic-source water, as reflected in the $\delta^{13} \mathrm{C}$ record as well as bottom-water warming (a decrease of $\delta^{18} \mathrm{O}$ in the latest Paleocene), might have triggered the benthic extinction event.

The extinction event at the end of the Paleocene (Zone CP8) occurred during an abrupt drop of $\delta^{13} \mathrm{C}$ values in benthic foraminifers (Fig. 9). In addition, there are two signals (near the Zone $\mathrm{CP} 3 / 4$ and CP4/5 boundaries) of the extinction event that have not been noted previously, though Miller et al. (1987) noted that the decrease of the Paleocene $S$. beccariiformis assemblage began in Zone P3b (CP4-CP5) in the Pacific Ocean (Site 577), and Thomas (1990b) also noted the change of the assemblages $6 / 7$ at the Zone CP4/5 boundary at Maud Rise. At Site 752 (middle to lower bathyal depths, $\sim 1000 \mathrm{~m}$, in the Paleocene; Peirce, Weissel, et al., 1989), the Stensioina beccariiformis assemblage belongs to the Velasco-type fauna. The gradual increase in abundance of Anomalinoides capitatus/A. danicus, Oridorsalis umbonatus, Bulimina tuxpamensis, and various species of Cibicidoides as represented by the Anomalinoides capitatus/A. danicus and Cibicidoides cf. pseudoperlucidus assemblages in late Paleocene to early Eocene indicates replacement of the Velasco-type fauna by a fauna more similar to the Midway-type fauna, suggesting shelf or upper bathyal depths (Plummer, 1926; Berggren and Aubert, 1975). The timing of the incursion of the Midway-type fauna is closely correlated with the interval of lowered d $13 \mathrm{C}$ (Fig. 9). The increase of taxa similar to those of the Midway fauna may be explained in two ways: (1) the shallowing of the crest of Broken Ridge up to shelf depths, and (2) depression of a shallower water mass to middle to lower bathyal depths. Rifting and shallowing of Broken Ridge occurred in the middle Eocene, and there is no evidence of shallowing of Broken Ridge during the Paleocene and earliest Eocene (Peirce, Weissel, et al., 1989); thus, it appears that shelf species migrated into this deeper environment. Thomas (1989) noted that the earliest Eocene faunas just after the Paleocene/Eocene boundary event probably migrated into the deep waters. Evidence for depth migration is also presented by Tjalsma and 


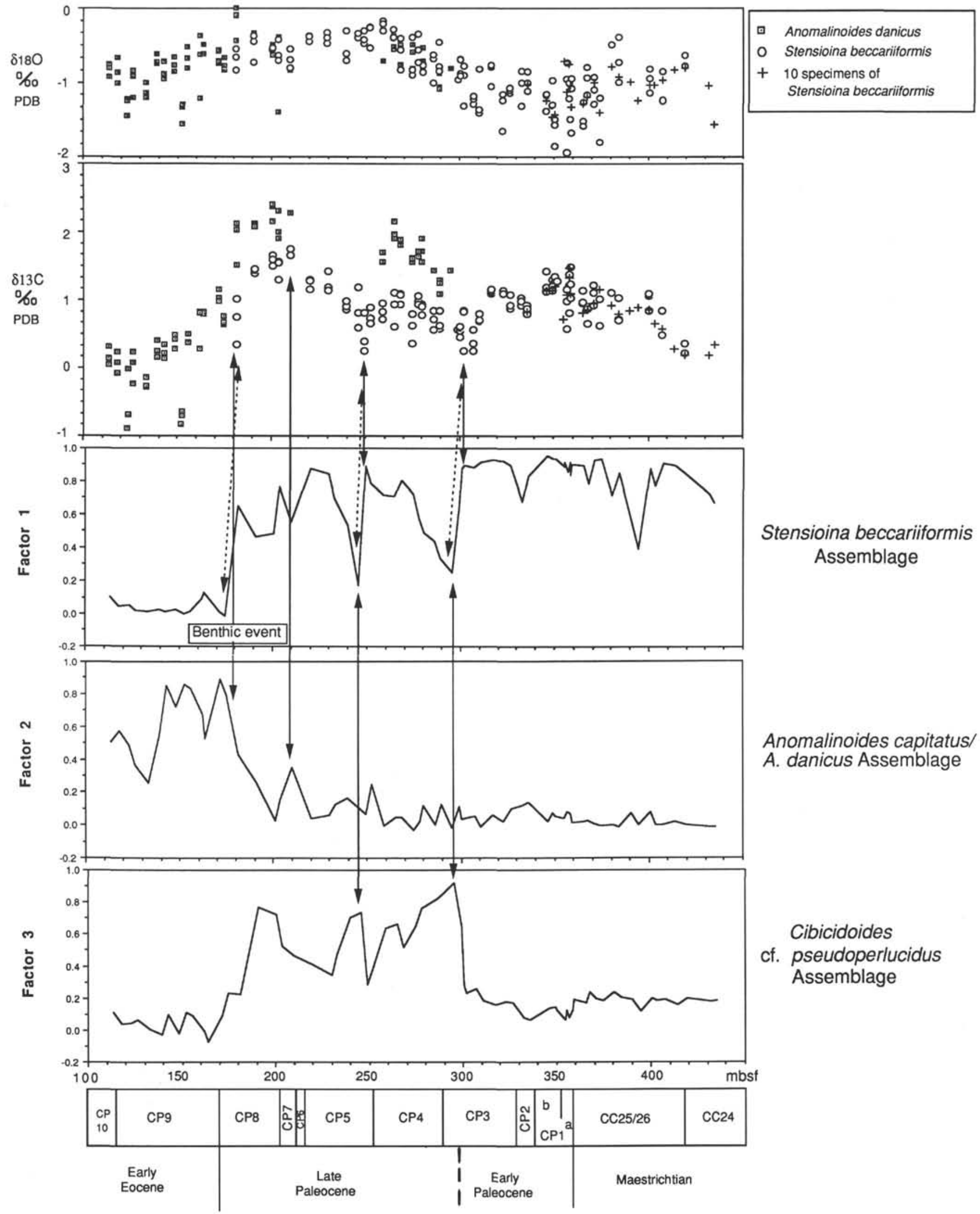

Figure 9. Relationships between oxygen and carbon isotope records (Seto et al., this volume) and benthic foraminiferal assemblages obtained from factor analysis (factors 1-3) from the upper Maestrichtian to lower Eocene. Arrows indicate the correlation between carbon isotope variations and benthic faunal changes, and the correlation between faunal variations. Dotted arrows indicate the correlation between the decreased values of $\delta^{13} \mathrm{C}$ and the reduced Stensioina beccariiformis assemblage in the Paleocene. 
Lohmann (1983); however, they described an upslope migration of Paleocene species that occurred at the latest Paleocene extinction and was followed by a bloom of new species in the early Eocene.

Benthic foraminiferal depth migration might be related to changes in ocean circulation, which may be caused by the reorganization of the ocean and continent configurations. Thomas (1989, 1990a, 1990b) and Katz and Miller (1990) suggested a relation between the extinction event and the production of warm, saline deep waters. Based on the isotopic data of the Antarctic sites, Kennett and Stott (1990) stated, "The ocean during the Eocene, and perhaps the Paleocene, is inferred to have been two-layered, consisting of warm, saline deep waters formed at low latitudes and overlain by cooler waters formed at high latitudes." The source region of such warm, saline deep water is suggested to have been the Tethys. According to Berggren and Aubert (1975), the upper Paleocene sediments surrounding the Tethys Sea in the North African region (LeRoy, 1953; Said and Kenawy, 1956; Berggren, 1974) are characterized by the "Tethyan Carbonate Fauna," shallow-water limestones containing larger foraminifers. The Cibicidoides-Anomalinoides assemblage developed as an offshore biofacies of the "Tethyan Carbonate Fauna" on a middle to outer shelf setting, in Zone P5 in the Sirte Basin of Libya (Berggren, 1974). Downslope migration of shallower-dwelling faunas may have been facilitated at this time.

A Proteus Ocean, characterized by halothermal circulation, is in contradiction to the interpretation of Miller et al. (1987) and Katz and Miller (1990) with respect to the source of deep water, although Katz and Miller (1990) suggested that the Antarctic deep-water source was replaced by the short period of warm, saline deep-water formation near the Paleocene/Eocene boundary (58-57 Ma). The warm, saline bottom-water model is based on the notion that more sources of warm, saline water existed during the Late Cretaceous (Brass et al., 1982) and during the Tertiary (Prentice and Matthews, 1989), due to the presence of large marginal seas lying in the net evaporation zone $\left(10^{\circ}-40^{\circ}\right.$ latitude). However, the marginal seas, including the Tethys Sea, contracted in size after the Cretaceous (Barron et al., 1981; Brass et al., 1982), which would correlate with a reduction of the warm, saline deep-water mass (Brass et al., 1982). Carbon isotopes reveal an inflow of young and nutrient-depleted waters in middle to lower bathyal depths at Zones CP7 and lower Zone CP8 (the interval of higher benthic $\delta^{13} \mathrm{C}$ values), and that warm and aged waters were not only formed during the latest Paleocene to early Eocene, but were also distinctly formed in short periods (near the boundaries of Zones CP3/4 and CP4/5) in the Paleocene at Site 752. The changes in carbon isotopic ratios of Anomalinoides danicus and Stensioina beccariiformis correlate with changes in $S$. beccariiformis, A. capitatus/danicus, and Cibicidoides cf. pseudoperlucidus assemblages (Fig. 9), which suggests that changes of bottom-water character caused faunal change. Although the deepwater source in the eastern Indian Ocean is not determinable at this site alone, Stott and Kennett (1989) indicated that the Antarctic may not have been a significant source of deep water during the early Paleocene, contrary to Barrera et al. (1987) and Miller et al. (1987). Stott et al. (1990) also suggested that sea-surface temperatures of the oceans surrounding Antarctica were temperate during much of the Paleocene and Eocene. If their conclusions are valid, I consider that the variations of warm, saline water originating from a low-latitude evaporation zone caused the changes in Paleocene and early Eocene benthic fauna. The Paleocene/Eocene extinction event seems to be reflected in the weakened influence of a warm, saline water circulation by the reduction of evaporation area of shallow marginal seas worldwide. This view is not in agreement with the previously mentioned conclusions that extinction resulted from the influence of warm, saline deep water because it is supposed to have higher $\delta^{18} \mathrm{O}$ and $\delta^{13} \mathrm{C}$ values (e.g., Railsback et al., 1989; Railsback, 1990); however, these isotopic values decreased from the late Paleocene to early Eocene.

In conclusion, several hypotheses have been advanced to explain the faunal turnover in relation to water circulation at the end of the Paleocene, such as a decrease of surface ocean productivity, a cessation of the deep-water flow from the Southern Ocean (Antarctic region) (Miller et al., 1987; Katz and Miller, 1990), and a concomitant inflow of warm, saline water from the low latitudes (Thomas, 1989, 1990a, 1990b; Kennett and Stott, 1990). The benthic fauna and their isotopic composition, however, suggest that the weakened influence of the warm, saline water flow from the Tethyan region was critical for the changes in Paleocene deep-sea taxa at Site 752. Aged and oxygen-depleted deep waters would have formed following the weakening circulation influence of the warm, saline water.

The Velasco-type fauna characterized by the Stensioina beccariiformis assemblage changed in response to at least three cessations of warm, saline bottom-water flow during the Paleocene. The benthic extinction event at the end of the Paleocene suggests a weakening influence of the warm, saline water on deep-ocean circulation.

\section{ACKNOWLEDGMENTS}

I thank Anne Boersma and an anonymous reviewer for their many constructive suggestions for improvement of this report. Ellen Thomas and James P. Kennett provided constructive comments that helped me to improve the manuscript, and Jeffrey Weissel and Elliott Taylor kindly helped me to complete it on time. I also thank the shipboard scientific party of Leg 121 and ODP staff for a great cruise and for preparation of this paper.

\section{SPECIES REFERENCE LIST}

Asterisks indicate the taxa that occurred from the Oligocene (Sample $121-752 \mathrm{~A}-10 \mathrm{H}-5,70-75 \mathrm{~cm}$ ) or from the lower Miocene (Sample 121$752 \mathrm{~A}-10 \mathrm{H}-1,70-75 \mathrm{~cm})$.

Alabamina creta $($ Finlay $)=$ Pulvinulinella creta Finlay, 1940

Alabamina dissonata $($ Cushman and Renz) $=$ Pulvinulinella atlantisae Cushman var. dissonata Cushman and Renz, 1943

Ammodiscus glabratus Cushman and Jarvis, 1928

Anomalina praeacuta Vasilenko, 1950

Anomalinoides capitatus (Gümbel) = Rotalia capitata Gümbel, 1868

Anomalinoides danicus $($ Brotzen) $=$ Cibicides danica Brotzen, 1940

*Anomalinoides pseudogrosserugosus $($ Colom $)=$ Anomalina pseudogrosserugosa Colom, 1945

Anomalinoides semicribratus $($ Beckmann $)=$ Anomalina pompilioides Galloway and Heminway var. semicribrata Beckmann, 1953

Anomalinoides spissiformis (Cushman and Stainforth) $=$ Anomalina alazanensis Nuttall var. spissiformis Cushman and Stainforth, 1945

Anomalinoides undulatus Belford, 1960

Aragonia aragonensis (Nuttall) $=$ Textularia aragonensis Nuttall, 1930

*Astrononion stelligerum (d'Orbigny) = Nonionina stelligera d'Orbigny, 1839

*Bolivina cf. B. silvestrina Cushman, 1936

*Bolivina cf. B. thalmanni Renz, 1948

Bolivinoides delicatulus $=$ Bolivinoides decorata $($ Jones $)$ var. delicatula Cushman, 1927

Bolivinoides draco $($ Marsson) $=$ Bolivina draco Marsson, 1878

Bulimina alazanensis Cushman, 1927

Bulimina bradbury Martin, 1943

Bulimina callahani Galloway and Morrey, 1931

Bulimina impendens Parker and Bermúdez, 1937

Bulimina jarvisi Cushman and Parker, 1936

Bulimina macilenta Cushman and Parker, 1939

Bulimina mexicana Cushman = Bulimina inflata Seguenza var. mexicana Cushman, 1922

Bulimina triangularis Cushman and Parker, 1935

Bulimina trinitatensis Cushman and Jarvis, 1928

Bulimina tuxpamensis Cole, 1928 
Buliminella grata Parker and Bermúdez, 1937

Cibicides excavata Brotzen, 1936

Cibicides cf. C. aknerianus (d'Orbigny) = Rotalina akneriana d'Orbigny, 1846

*Cibicides lobatulus $(\mathrm{W}$ alker and Jacob) $=$ Nautilus lobatulus Walker and Jacob, 1798

Cibicides cf. C. ribbingi Brotzen, 1936

Cibicidina walli Bandy, 1949

Cibicidoides $\mathrm{cf}$. C. alazanensis $($ Nuttall $)=\mathrm{Cf}$. Anomalina alazanensis $\mathrm{Nuttall}$, 1932

Cibicidoides bradyi $($ Trauth $)=$ Truncatulina bradyi Trauth, 1918

Cibicidoides dayi $($ White $)=$ Planulina dayi White, 1928

Cibicidoides eocaenus $($ Gümbel $)=$ Rotalia eocaena Gümbel, 1868

Cibicidoides grimsdale $i($ Nuttall $)=$ Cibicides grimsdale $i$ Nuttall, 1930

Cibicidoides havanensis (Cushman and Bermúdez) $=$ Cibicides havanensis Cushman and Bermúdez, 1937

Cibicidoides hyphalus $($ Fisher $)=$ Anomalinoides hyphalus Fisher, 1969

Cibicidoides $\mathrm{cf}$. C. incrassatus (Fichtel and Moll) $=\mathrm{Cf}$. Nautilus incrassatus Fichtel and Moll, 1798

Cibicidoides laurisae (Mallory) $=$ Cibicides laurisae Mallory, 1959

Cibicidoides mundulus $($ Brady, Parker, and Jones) $=$ Truncatulina mundula Brady, Parker, and Jones, 1888

Cibicidoides cf. C. pseudoperlucidus $($ Bykova $)=$ Cf. Cibicides $($ Gamellides) pseudoperlucidus Bykova,

Cibicidoides subspiratus $($ Nuttall $)=$ Cibicides subspiratus Nuttall, 1930

Cibicidoides truncanus $($ Gümbel $)=$ Rotalia truncana Gümbel, 1868

Cibicidoides tuxpamensis $($ Cole $)=$ Cibicides tuxpamensis Cole, 1928

Cibicidoides velascoensis $($ Cushman $)=$ Anomalina velascoenis Cushman, 1925

Coryphostoma incrassata (Reuss) $=$ Bolivina incrassata Reuss, 1851

Coryphostoma midwayensis $($ Cushman $)=$ Bolivina midwayenis Cushman, 1936

Dentalina admodicostata Belford, 1960

Dentalina basiplanata Cushman, 1938

Dentalina colei Cushman and Dusenbury, 1934

* Dentalina communis d'Orbigny, 1826

Dentalina cylindroides Reuss, 1860

Dentalina jacksonensis $($ Cushman and Applin $)=$ Nodosaria jacksonensis Cushman and Applin, 1926

Dentalina luma Belford, 1960

Dentalina multilineata Bomemann, 1855

Dentalina obliquata $($ Batsch $)=$ Nautilus $($ Orthoceras $)$ obliquatus Batsch, 1791

Dentalina pseudoaculeata Olsson, 1960

Dorothia beloides Hillebrandt, 1962

Dorothia bulletta $($ Carsey $)=$ Gaudryina bulletta Carsey, 1926

Dorothia conicula Belford, 1960

Dorothia cf. D. oxycona $=$ Cf. Dorothia oxycona Reuss, 1860

Dorothia trochoides $($ Marsson $)=$ Gaudryina crassa Marsson var. trochoides Marsson, 1878

Ellipsoidella $\mathrm{cf}$. E. solida $($ Brotzen $)=$ Cf. Nodosarella solida Brotzen, 1936

Ellipsoidina ellipsoides Seguenza, 1859

Eouuvigerina cf.E. americana Cushman, 1926

Frondicularia cf. F. steinekei Finley, 1939

Frondicularia teuria Finley, 1939

Gaudryina cf. G. laevigata Franke, 1914

Gaudryina pyramidata Cushman = Gaudryina laevigata Franke var. pyramidata Cushman, 1926

Globocassidulina globosa (Hantken) = Cassidulina globos $a$ Hantken, 1875

Globocassidulina punctata van Morkhoven, Berggren, and Edwards, 1986

Globorotalites conicus (Carsey) =Truncatulina refulgens Montfort var. conica Carsey, 1926

Globulina gibba d'Orbigny, 1826

Guttulina problema d'Orbigny, 1826

Guttulina cf. G. trigonula (Reuss) = Cf. Polymorphina trigonula Reuss, 1845

Gyroidina noda Belford, 1960

Gyroidina orbicularis d'Orbigny, 1826

Gyroidina soldanii d'Orbigny, 1826

Gyroidinoides globosus $($ Hagenow) $=$ Nonionia globosa Von Hagenow, 1842

Gyroidinoides excertus (Belford) = Cf. Gyroidina excerta Belford, 1960

Gyroidinoides planulatus $($ Cushman and Renz $)=$ Gyroidina planulata Cushman and Renz, 1941

Gyroidinoides quadratus (Cushman and Church) $=$ Gyroidina quadrata Cushman and Church, 1929

Hanzawaia ammophila (Gümbel) = Rotalia ammophila Gümbel, 1868

Hemicristellaria fragaria $($ Gümbel) $=$ Marginulina fragaria Gümbel, 1870
Heronallenia sp. "A," Boltovskoy, 1978

Karreriella chapapotensis $($ Cole $)=$ Textularia chapapotensis Cole, 1928

Karreriella subglabra $($ Gümbel $)=$ Gaudryina subglabra Gümbel, 1868

*Laticarinina pauperata (Parker and Jones) = Pulvinulina repanda var. menardii subvar. pauperata Parker and Jones, 1865

Lenticulina alato-limbata $($ Gümbel $)=$ Robulina alato-limbata Gümbel, 1868

Lenticulina callifer $a($ Stache $)=$ Cristellaria callifer $a$ Stache, 1864

Lenticulina caroliniana Cushman, 1933

Lenticulina chambersi Garrett, 1939

Lenticulina convergens $($ Bornemann $)=$ Cristellaria convergens Bornemann, 1855

Lenticulina lucida $($ Cushman $)=$ Cristellaria lucida Cushman, 1923

${ }^{*}$ Lenticulina nuttalli $($ Cushman and Renz) $=$ Robulus nuttalli Cushman and Renz, 1941

Lenticulina occidentalis $($ Cushman $)=$ Cristellaria occidentalis Cushman, 1923

Lenticulina occidentalis torridus $($ Cushman $)=$ Cristellaria occidentalis torrida Cushman, 1923

Lenticulina pseudovortex Cole, 1927

*Lenticulina rotulata $($ Lamarck $)=$ Lenticulites rotulata Lamarck, 1806

Lenticulina whitei Tjalsma and Lohmann, 1983

Melonis pompilioides $($ Fichtel and Moll) $=$ Nautilus ponpilioides Fitchel and Moll, 1798

Neoflabellina semireticulata $($ Cushman and Jarvis $)=$ Flabellina semireticulata Cushman and Jarvis, 1928

Nodosarella subnodosa $($ Guppy $)=$ Ellipsoidina subnodosa Guppy, 1891

Nodosaria cf. N. catenulata Cushman, 1923

Nodosaria cf. $N$. fistuca Schwager, 1866

Nodosaria hispida Schwager, 1866

Nodosaria limbata d'Orbigny, 1840

*Nodosaria pyrula d’Orbigny, 1826

Nodosaria soluta (Reuss) $=$ Dentalina soluta Reuss, 185

Nodosaria vertebralis $($ Batsch) $=$ Nautilus $($ Orthoceras) vertebralis Batsch, 1791

Nonion havanense Cushman and Bermúdez, 1937

Nuttallides truempyi $($ Nuttall $)=$ Eponides truempyi Nuttall, 1930

Nuttallinella florealis (White) = Gyroidina florealis White, 1928

Oridorsalis umbonatus (Reuss) = Gotalina umbonata Reuss,1851

Orthomorphina antille $a($ Cushman $)=$ Nodosaria antillea Cushman, 1923

* Orthomorphina challengeriana $($ Thalmann $)=$ Nodogenerina challengeriana Thalmann, 1937

Orthomorphina havanensis (Cushman and Bermúdez) $=$ Nodogenerina havanensis Cushman and Bermúdez, 1937

Orthomorphina heterosculpta $($ Bermúdez $)=$ Nodogenerina heterosculpta Bermúdez, 1949

*Orthomorphina modesta $($ Bermúdez $)=$ Ellipsonodosaria modesta Bermúdez, 1937

Osangularia cordieriana (d'Orbigny) $=$ Rotalina cordieriana d'Orbigny, 1940

Osangularia mexicana $($ Cole $)=$ Pulvinulinella culter $($ Parker and Jones) var. mexicana Cole, 1927

Osangularia velascoensis $($ Cushman $)=$ Truncatulina velascoensis Cushman, 1925

Planulina costata $($ Hantken $)=$ Truncatulina costata Hantken, 1875

*Planulina renzi Cushman and Stainforth, 1945

*Plectofrondicularia parri Finely, 1939

Pleurostomella acuminata Cushman, 1922

Pleurostomella acuta Hantken, 1875

Pleurostomella alternans Schwager, 1866

*Pleurostomella brevis Schwager, 1966

Pleurostomella incrassata Hantken, 1883

Praebulimina navarroensis (Cushman and Parker) $=$ Bulimina reussi var. navarroensis Cushman and Parker, 1935

Pullenia americana Cushman, 1936

*Pullenia bulloides (d'Orbigny) = Nonionia bulloides d'Orbigny, 1846

Pullenia coryelli White, 1929

Pullenia cretacea Cushman, 1936

Pullenia eocenica Cushman and Siegfus, 1939

Pullenia osloensis Feyling-Hanssen, 1954

Pullenia quadriloba Reuss = Pullenia compressiuscula Reuss var. quadriloba Reuss, 1867

Pullenia quinqueloba (Reuss) $=$ Nonionia quinqueloba Reuss, 1851

Pullenia reussi Cushman and Todd, 1943

Pullenia subcarinata (d'Orbigny) $=$ Nonionina subcarinata d'Orbigny, 1839

Pyramidina rudita (Cushman and Parker) = Bulimina rudita Cushman and Parker, 1935 
Quadrimorphina allomorphinoides (Reuss) = Valvulina allomorphinoides Reuss, 1860

Ramulina globulifera Brady, 1879

Remessella varians (Glaessner) $=$ Textulaniella ? variance Glaessner, 1937

*Sphaeroidina bulloides d'Orbigny, 1826

Spiroplectammina spectabilis (Grzybowski) = Spiroplecta spectabilis Grzybowski, 1898

Stensioina beccariiformis (White) = Rotalia beccariiformis White, 1928

Stilostomella aculeata $($ Cushman and Renz $)=$ Ellipsonodosaria nuttalli Cushman and Jarvis var. aculeata Cushman and Renz, 1948

Stilostomella annulifera $($ Cushman and Bermudez) $=$ Ellipsonodosaria annulifera Cushman and Bermudez, 1936

*Stilostomella fistuca (Schwager) = Nodosaria fistuca Schwager, 1866

Stilostomella gracillima (Cushman and Jarvis) $=$ Ellipsonodosaria nuttalli Cushman and Jarvis var. gracillima Cushman and Jarvis, 1934

Stilostomella lepidula $($ Schwager $)=$ Nodosaria lepidula Schwager, 1866

Stilostomella modesta $($ Bermudez $)=$ Ellipsonodosaria modesta Bermudez, 1937

Stilostomella subspinosa $($ Cushman $)=$ Ellipsonodosaria subspinosa Cushman, 1943

Trifarina wilcoxensis $($ Cushman and Ponton $)=P$ seudouvigerina wilcoxensis Cushman and Ponton, 1932

Tritaxia amorpha $($ Cushman $)=$ Clavulina amorpha Cushman, 1926

Tritaxia globulifera $($ ten Dam and Sigal $)=P$ seudoclavulina globulifera ten Dam and Sigal, 1950

Tritaxia paleocenica Tjalsma and Lohmann, 1983

Turrilina brevispira ten Dam, 1944

Uvigerina elongata Cole, 1927

Uvigerina finelineata Keijzer, 1945

*Uvigerina cf. mantaensis Cushman and Edwards, 1938

Uvigerina resurgens Boersma, 1984

Vaginulina mexicana Nuttall, 1932

Vulvulina mexicana Nuttall $=$ Vulvulina pectinata Hantken var. mexicana Nuttall, 1930

Vulvulina spinosa Cushman, 1927

\section{REFERENCES}

Arthur, M. A., Zachos, J. C., and Jones, D. S., 1987. Primary productivity and the Cretaceous/Tertiary boundary event in the oceans. Cretaceous Res., 8:43-54.

Aubry, M.-P., Berggren, W. A., Kent, D. V., Flynn, J. J., Klitgord, K. D., Obradovich, J. D., and Prothero, D. R., 1988. Paleogene geochronology: an integrated approach. Paleoceanography, 3:707-742.

Barrera, E., Huber, B. T., Savin, S. M., and Webb, P. N., 1987. Antarctic marine temperatures: late Campanian through early Paleocene. Paleoceanography, 2:21-48.

Barron, E. J., 1987. Eocene equator-to-pole surface ocean temperatures: a significant climate problem? Paleoceanography, 2:729-740.

Barron, E. J., Harrison, C.G.A., Sloan, J. L., II, and Hay, W., 1981. Paleogeography, 180 million years ago to the present. Eclogae Geol. Helv., 74:443-470.

Beckmann, J.-P., 1960. Distribution of benthonic foraminifera at the Cretaceous-Tertiary boundary of Trinidad (West-Indies). Inter. Geol. Congr., Rep. 21st Session, Norden. Part V: The Cretaceous-Tertiary Boundary, 57-69.

Beckmann, J.-P., Bolli, H. M., Kleboth, P., and Proto-Decima, F., 1982. Micropaleontology and biostratigraphy of the Campanian to Paleocene of the Monte Giglio, Bergamo Province, Italy. Mem. Sci. Geol., Univ. Padova, 35:91-172.

Berggren, W. A., 1974. Paleocene benthonic foraminiferal biostratigraphy, biogeography and paleoecology of Libya (Sirte Basin) and Mali. Micropaleontology, 20:449-465.

Berggren, W. A., and Aubert, J., 1975. Paleocene benthonic foraminiferal biostratigraphy, paleobiogeography and paleoecology of AtlanticTethyan region: Midway-type fauna. Palaeogeogr., Palaeoclimatol., Palaeoecol., 18:73-192.

Berggren, W. A., Kent, D. V., Flynn, J. J., and Van Couvering, J. A., 1985. Cenozoic geochronology. Geol. Soc. Am. Bull., 96:1407-1418.

Berggren, W. A., and Miller, K. G., 1989. Cenozoic bathyal and abyssal calcareous benthic foraminiferal zonations. Micropaleontology, $35: 308-320$.

Boersma, A., 1984. Campanian through Paleocene paleotemperature and carbon isotope sequence and the Cretaceous-Tertiary boundary in the
Atlantic Ocean. In Berggren, W. A., and Van Couvering, J. A. (Eds.), Catastrophes and Earth History: Princeton (Princeton Univ. Press), 247-277.

Boersma, A., and Shackleton, N. J., 1981. Oxygen- and carbon-isotope variations and planktonic foraminifer depth habitat, Late Cretaceous to Paleocene, Central Pacific. In Thiede, J., Vallier, T. L., et al., Init. Repts. DSDP, 62: Washington (U.S. Govt. Printing Office), 513-526.

Boltovskoy, E., and Boltovskoy, D., 1989. Paleocene-Pleistocene benthic foraminiferal evidence of major paleoceanographic events in the eastern South Atlantic (DSDP Site 525, Walvis Ridge). Mar. Micropaleontol., 14:283-316.

Brass, G. W., Southam, J. R., and Peterson, W. H., 1982. Warm saline bottom water in the ancient ocean. Nature, 296:620-623.

Corliss, B. H., and Chen, C., 1988. Morphotype patterns of Norwegian Sea deep-sea benthic foraminifera and ecological implications. Geology, 16:716-719.

Corliss, B. H., and Keigwin, L. D., 1986. Eocene/Oligocene paleoceanography. In Hsü, K. J. (Ed.), Mesozoic and Cenozoic Oceans: Am. Geophys. Union Geodyn. Ser., 15:101-118.

Culver, S., 1987. Foraminifera. In Lipps, J. H. (Ed.), Fossil Prokaryotes and Protists. Univ. of Tenn. Studies in Geol., 18:169-212.

Dailey, D. H., 1983. Late Cretaceous and Paleocene benthic foraminifers from Deep Sea Drilling Project Site 516, Rio Grande Rise, western South Atlantic Ocean. In Barker, P. F., Carlson, R. L., et al., Init. Repts. DSDP, 72: Washington (U.S. Govt. Printing Office), 757-782.

Douglas, R. G., and Woodruff, F., 1981. Deep-sea benthic foraminifera In Emiliani, C. (Ed.), The Sea (Vol. 7): New York (Wiley-Interscience), 1233-1327.

Hsü, K. J., 1986. Cretaceous/Tertiary boundary event. In Hsü, K. J. (Ed.), Mesozoic and Cenozoic Oceans. Am. Geophys. Union Geodyn. Ser., 15:75-84.

Katz, M. R., and Miller, K. G., 1991. Early Paleocene benthic foraminiferal assemblage and stable isotopes in the Southern Ocean. In Ciesielski, P. F., Kristofferson, Y., et al., Proc. ODP, Sci. Results, 114: College Station, TX (Ocean Drilling Program), 481-512.

Keller, G., 1988. Biotic turnover in benthic foraminifera across the Cretaceous/Tertiary boundary at El Kef, Tunisia. Palaeogeogr., $\mathrm{Pa}$ laeoclimatol., Palaeoecol., 66:153-171.

1989. Stable isotope, TOC and $\mathrm{CaCO}_{3}$ record across the Cretaceous/Tertiary boundary at El Kef, Tunisia. Palaeogeogr., Palaeoclimatol., Palaeoecol., 73:243-265.

Kennett, J. P., and Stott, L. D., 1990. Proteus and Proto-Oceanus: ancestral Paleogene oceans as revealed from Antarctic stable isotopic results: ODP Leg 113. In Barker, P. F., Kennett, J. P., et al., Proc. $O D P$, Sci. Results, 113: College Station, TX (Ocean Drilling Program), 865-880.

Klovan, J. E., and Imbrie, J., 1971. An algorithm and fortran IV program for large scale Q-mode factor analysis. J. Int. Assoc. Math. Geol., 3:61-78.

Kurihara, K., and Kennett, J. P., 1985. Neogene benthic foraminifers: distribution in depth traverse, Southwest Pacific. In Kennett, J. P., von der Borch, C. C., et al., Init. Repts. DSDP, 90: Washington (U.S. Govt. Printing Office), 1037-1077.

LeRoy, L. W., 1953. Biostratigraphy of the Maqfi section, Egypt. Mem. Geol. Soc. Am., 54:1-73.

Miller, K. G., and Fairbanks, R. G., 1985. Oligocene-Miocene global carbon and abyssal circulation changes. In Sundquist, E. J., and Broecker, W. S. (Eds.), The Carbon Cycle and Atmospheric $\mathrm{CO}_{2}$ : Natural Variations, Archean to Present. Am. Geophys. Union Monogr. Series, 32:469-486.

Miller, K. G., Janecek, T. R., Katz, M. E., and Keil, D. J., 1987. Abyssal circulation and benthic foraminiferal changes near the Paleocene/Eocene boundary. Paleoceanography, 2:741-761.

Oberhänsli, H., and Hsü, K. J., 1986. Paleocene-Eocene paleoceanography. In Hsü, K. J. (Ed.), Mesozoic and Cenozoic Oceans. Am. Geophys. Union Geodyn. Ser., 15:85-100.

Oberhänsli, H., McKenzie, J. A., Toumarkine, M., and Weissert, H., 1984. A paleoclimatic and paleoceanographic record of the Paleogene in the central South Atlantic (Leg 73, Sites 522, 523, and 524). In Hsü, K. J., LaBrecque, J. L., et al., Init. Repts. DSDP, 73: Washington (U.S. Govt. Printing Office), 737-747.

Officer, C. B., Hallam, A., Drake, C. L., and Devine, J. D., 1987. Late Cretaceous and paroxysmal Cretaceous/Tertiary extinctions. Nature, $326: 143-149$. 
Owen, R. M., and Rea, D. K., 1985. Sea-floor hydrothermal activity links climate to tectonics: the Eocene $\mathrm{CO}_{2}$ greenhouse. Science, 227:166169.

Peirce, J., Weissel, J., et al., 1989. Proc. ODP, Init. Repts., 121: College Station, TX (Ocean Drilling Program).

Plummer, H. J., 1926. Foraminifera of the Midway formation in Texas. Texas Univ. Bull., 2644.

Prentice, M. L., and Matthews, R. K., 1988. Cenozoic ice-volume history: development of a composite oxygen isotope record. Geology, 16:963-966.

Railsback, L. B., 1990. Influence of changing deep ocean circulation on the Phanerozoic oxygen isotopic record, Geochim. Cosmochim. Acta., 54:1501-1509.

Railsback, L. B., Anderson, T. F., Ackerly, S. C., and Cisne, J. L., 1989. Paleoceanographic modeling of temperature-salinity profiles from stable isotopic data. Paleoceanography, 4:585-591.

Rea, D. K., Dehn, J., Driscoll, N., Farrell, J., Janecek, T., Owen, R. M., Pospichal, J. L., Resiwati, P., and the ODP Leg 121 Scientific Party, 1990. Paleoceanography of the eastern Indian Ocean from ODP Leg 121 drilling on Broken Ridge. Geol. Soc. Am. Bull., 102:679-690.

Rea, D. K., Zachos, J. C., Owen, R. M., and Gingerich, P. D., 1990. Global change at the Paleocene-Eocene boundary: climatic and evolutionary consequences of tectonic events. Palaeogeogr., Palaeoclimatol., Palaeoecol., 79:117-128.

Said, R., and Kenawy, A., 1956. Upper Cretaceous and lower Tertiary foraminifera from northern Sinai, Egypt. Micropaleontology, 2:105173.

Savin, S. M., 1977. The history of the Earth's surface temperature during the past 100 million years. Annu. Rev. Earth Planet Sci., 5:319-355.

Schnitker, D., 1979. Cenozoic deep-water benthic foraminifera, Bay of Biscay. In Montadert, L., Roberts, D. G., et al., Init. Repts. DSDP, 48: Washington (U.S. Govt. Printing Office), 377-414.

Shackleton, N. J., 1986. Paleogene stable isotope events. Palaeogeogr., Palaeoclimatol., Palaeoecol., 57:91-102.

Shackleton, N. J., and Hall, M. A., 1984. Carbon isotope data from Leg 74 sediments. In Moore, T. C., Jr., Rabinowitz, P. D., et al., Init. Repts. DSDP, 74: Washington (U.S. Govt. Printing Office), 613-619.

Shackleton, N. J., Hall, M. A., and Bleil, U., 1985. Carbon isotope stratigraphy, Site 577. In Heath, G. R., Burckle, L. H., et al., Init. Repts. DSDP, 86: Washington (U.S. Govt. Printing Office), 503-511.

Shackleton, N. J., Hall, M. A., and Boersma, A., 1984. Oxygen and carbon isotope data from Leg 74 foraminifers. In Moore, T. C., Jr., Rabinowitz, P. D., et al., Init. Repts. DSDP, 74: Washington (U.S. Govt. Printing Office), 599-612.

Sheehan, P. M., and Hansen, T. A., 1986. Detritus feeding as a buffer to extinction at the end of the Cretaceous. Geology, 14:868-870.

Sigal, J., 1974. In site report 245: biostratigraphy, Paleogene foraminifera. In Simpson, E.S.W., Schlich, R., et al., Init. Repts. DSDP, 25: Washington (U.S. Govt. Printing Office), 199-203.
Stott, L. D., and Kennett, J. P., 1989. New constraints on early Tertiary paleoproductivity from carbon isotopes in foraminifera. Nature, 342:526-529.

Stott, L. D., Kennett, J. P., Shackleton, N. J., Corfield, R. M., 1990. The evolution of Antarctic surface waters during the Paleogene: inferences from stable isotopic composition of planktonic foraminifers, ODP Leg 113. In Barker, P. F., Kennett, J. P., et al., Proc. ODP, Sci. Results, 113: College Station, TX (Ocean Drilling Program), 849-863.

Thomas, E., 1989. Development of Cenozoic deep-sea benthic foraminiferal faunas in Antarctic waters. In Crame, J. A. (Ed.), Origins and Evolution of Antarctic Biota. Geol. Soc. Spec. Publ. London, 47:283-296.

1990. Late Cretaceous through Neogene deep-sea benthic foraminifers (Maud Rise, Weddell Sea, Antarctica). In Barker, P. F., Kennett, J. P., et al., Proc. ODP, Sci. Results, 113: College Station, TX (Ocean Drilling Program), 571-594.

, in press. Mass extinctions in the deep sea. In Sharpton, V., and Ward, P. (Eds.), Proceedings of the Conference on Global Catastrophes in Earth History: An Interdisciplinary Conference on Impacts, Volcanism, and Mass Mortality. Spec. Pap. Geol. Soc. Am., 247.

Tjalsma, R. C., 1976. Cenozoic foraminifera from the South Atlantic, DSDP Leg 36. In Barker, P. F., Dalziel, I.W.D., et al., Init. Repts. DSDP, 36: Washington (U.S. Govt. Printing Office), 493-518.

Tjalsma, R. C., and Lohmann, G. P., 1983. Paleocene-Eocene bathyal and abyssal benthic foraminifera from the Atlantic Ocean. Micropaleontol. Spec. Publ., 4:1-90.

van Morkhoven, F.P.C.M., Berggren, W. A., and Edwards, A. S., 1986. Cenozoic cosmopolitan deep-water benthic foraminifera. Bull. Cent. Rech. Explor.-Prod. Elf-Aquitaine, Mem. 11

Vincent, E., Gibson, J. M., and Brun, L., 1974. Paleocene and early Eocene microfacies, benthonic foraminifera and paleobathymetry of Deep Sea Drilling Project Sites 236 and 237, western Indian Ocean. In Fisher, R, L., Bunce, E. T., et al., Init. Repts, DSDP, 24: Washington (U.S. Govt. Printing Office), 859-885.

Webb, P.-N., 1973. Upper Cretaceous-Paleocene foraminifera from Site 208 (Lord Howe Rise, Tasman Sea), DSDP, Leg 21. In Burns, R. E. Andrews, J. E., et al., Init. Repts. DSDP, 21: Washington (U.S. Govt. Printing Office), 541-573.

Woodruff, F., and Savin, S. M., 1989. Miocene deepwater oceanography. Paleoceanography, 4:87-140.

Date of initial receipt: 13 March 1990

Date of acceptance: 12 December 1990

Ms 121B-138 


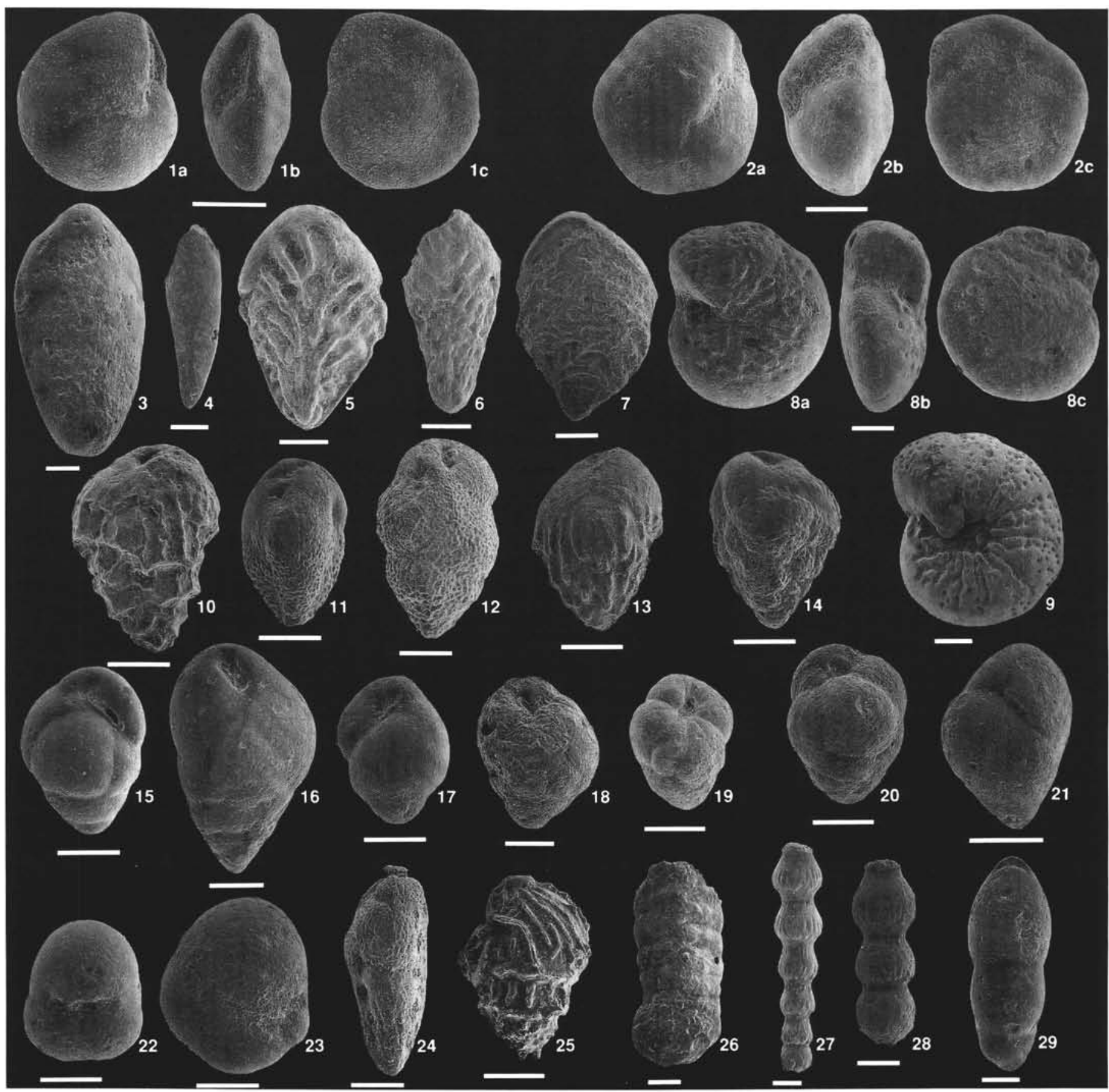

Plate 1. (Scale bar $=100 \mu \mathrm{m}$.) 1a-c. Alabamina dissonata (Cushman and Renz). Sample 121-752A-13X-1, $70-75 \mathrm{~cm}$. 2a-c. Alabamina creta (Finlay). Sample 121-752A-33X-1, 68-71 cm. 3. Coryphostoma incrassata (Reuss). Sample 121-752B-11R-1, $44-47 \mathrm{~cm}$. 4. Coryphostoma midwayensis (Cushman). Sample 121-752A-26X-5, 97-100 cm. 5. Bolivinoides draco (Marsson). Sample 121-752B-14R-5, 62-65 cm. 6. Bolivinoides delicatulus (Cushman). Sample 121-753A-21X-1, 70-75 cm. 7. Aragonia aragonensis (Nuttall). Sample 121-752B-8R-6, 101-104 cm. 8a-c, 9. Stensioina beccariiformis (White). Sample 121-752A-27X-1, 70-75 cm. 10. Bulimina trinitatensis Cushman and Jarvis. Sample 121-752A-16X-1, 70-75 cm. 11. Bulimina triangularis Cushman and Parker. Sample 121-752B-19R-3, 49-52 cm. 12. Bulimina bradbury Martin. Sample 121-752B-19R-3, 49-52 cm. 13. Bulimina macilenta Cushman and Parker. Sample 121-752A-15X-5, 70-75 cm. 14. Pyramidina sp. Sample 121-752A-21X-1, 70-75 cm. 15. Turrilina brevispira ten Dam. Sample 121-752A-13X-4, 62-67 cm. 16. Praebulimina navarroensis (Cushman and Parker). Sample 121-752A-21X-1, 70-75 cm. 17. Buliminella sp. 1. Sample 121-752B-11X-3, 112-114 cm. 18. Praebulimina sp. 2. Sample 121-752A-19X-3, 75-79 cm. 19. Buliminella grata (Parker and Bermúdez). Sample 121-752A-22X-3, 70-75 cm. 20. Praebulimina sp. 1. Sample 121-752A-21X-1, 70-75 cm. 21. Praebulimina sp. B. Sample 121-752B-16R-3, 136-138 cm. 22. Allomorphina sp. Sample 121-752B-7R-5, 76-78 $\mathrm{cm}$. 23. Quadrimorphina allomorphinoides (Reuss). Sample 121-752B-7R-1, 82-85 cm. 24. Trifarina wilcoxensis (Cushman and Ponton). Sample 121-752A$11 \mathrm{H}-1,70-75 \mathrm{~cm}$. 25. Uvigerina sp. Sample 121-752A-11H-1, 70-75 cm. 26. Spiroplectammina spectabilis (Grzybowski). Sample 121-752A-27X-1, 70-75 cm. 27, 28. Stilostomella gracillima (Cushman and Jarvis). Samples 121-752A-23X-1, $54-56 \mathrm{~cm}$, and 121-752A-26X-5, 97-100 cm. 29. Ellipsoidella sp. A. Sample $121-752 \mathrm{~B}-5 \mathrm{R}-3,50-53 \mathrm{~cm}$. 


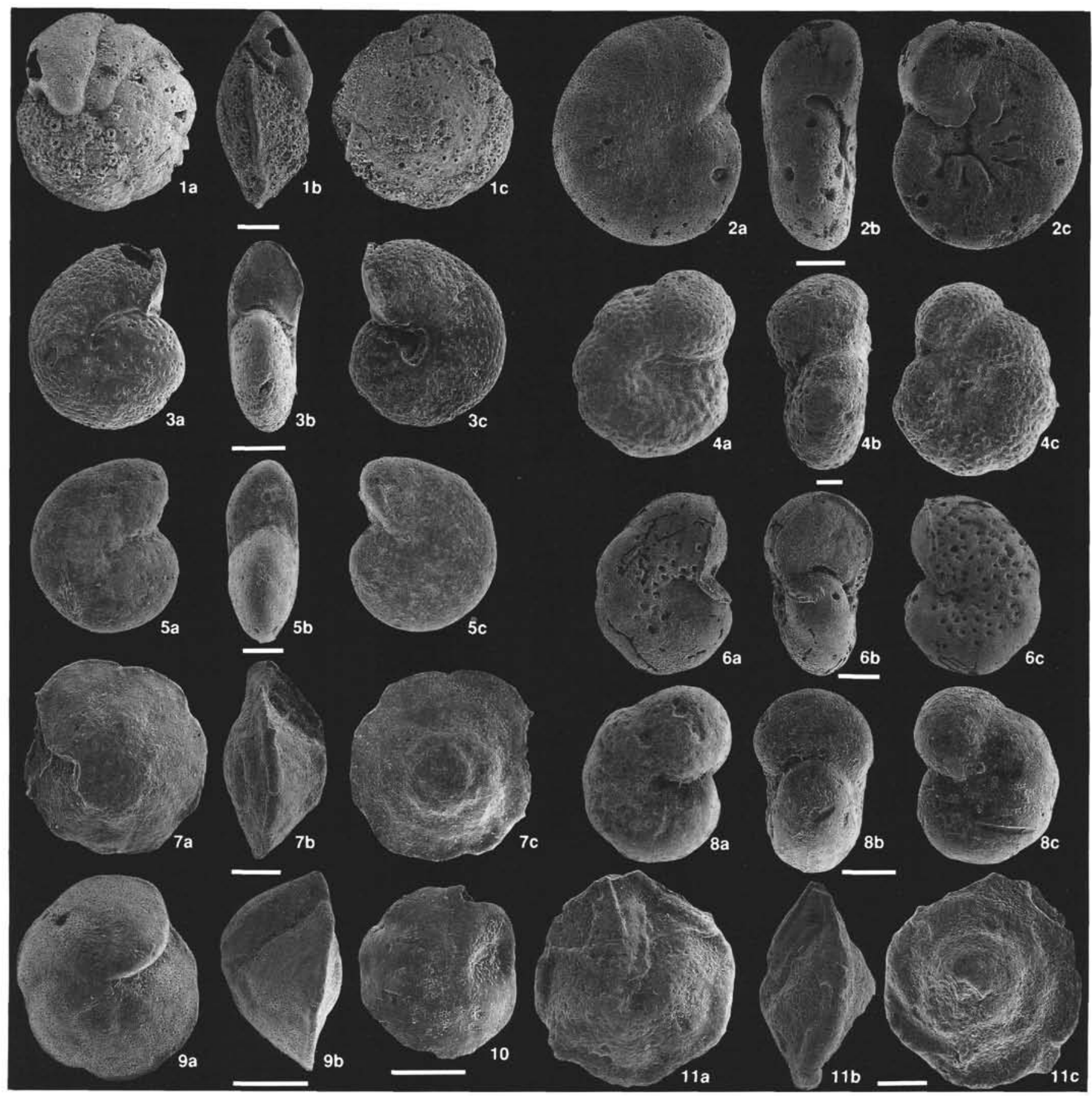

Plate 2. (Scale bar $=100 \mu \mathrm{m}$ ) 1a-c. Cibicidoides truncanus (Gümbel). Sample 121-752A-11H-5, 70-75 cm. 2a-c. Hanzawaia ammophila (Gümbel). Sample 121-742A-11H-5, 70-75 cm. 3a-c. Anomalinoides spissiformis (Cushman and Stainforth). Sample 121-752A-15X-1, 70-75 cm. 4a-c. Anomalinoides danicus (Brotzen). Sample 121-752A-32X-1, 70-75 cm. 5a-c. Anomalinoides praeacuta (Vasilenko). Sample 121-752B-12R-1, 104-107 cm. 6a-c. Anomalinoides pseudogrosserugosus (Colum). Sample 121-752A-10H-1, 70-75 cm. 7a-c, 9a-b, 10. Nuttallides truempyi (Nuttall) with distinct transparent umbilical mass. Sample 121-752A-18X-1, 71-75 cm, N. truempyi without umbilical mass. Sample 121-752A-13X-1, 70-75 cm, thin-shaped N. truempyi. Sample 121-752A 26X-1, 70-75 cm. 8a-c. Anomalinoides semicribratus (Beckmann). Sample 121-752A-26X-1, 97-100 cm. 11a-c. Nuttallinella florealis (White). Sample $121-752 \mathrm{~A}-19 \mathrm{R}-3,49-52 \mathrm{~cm}$. 


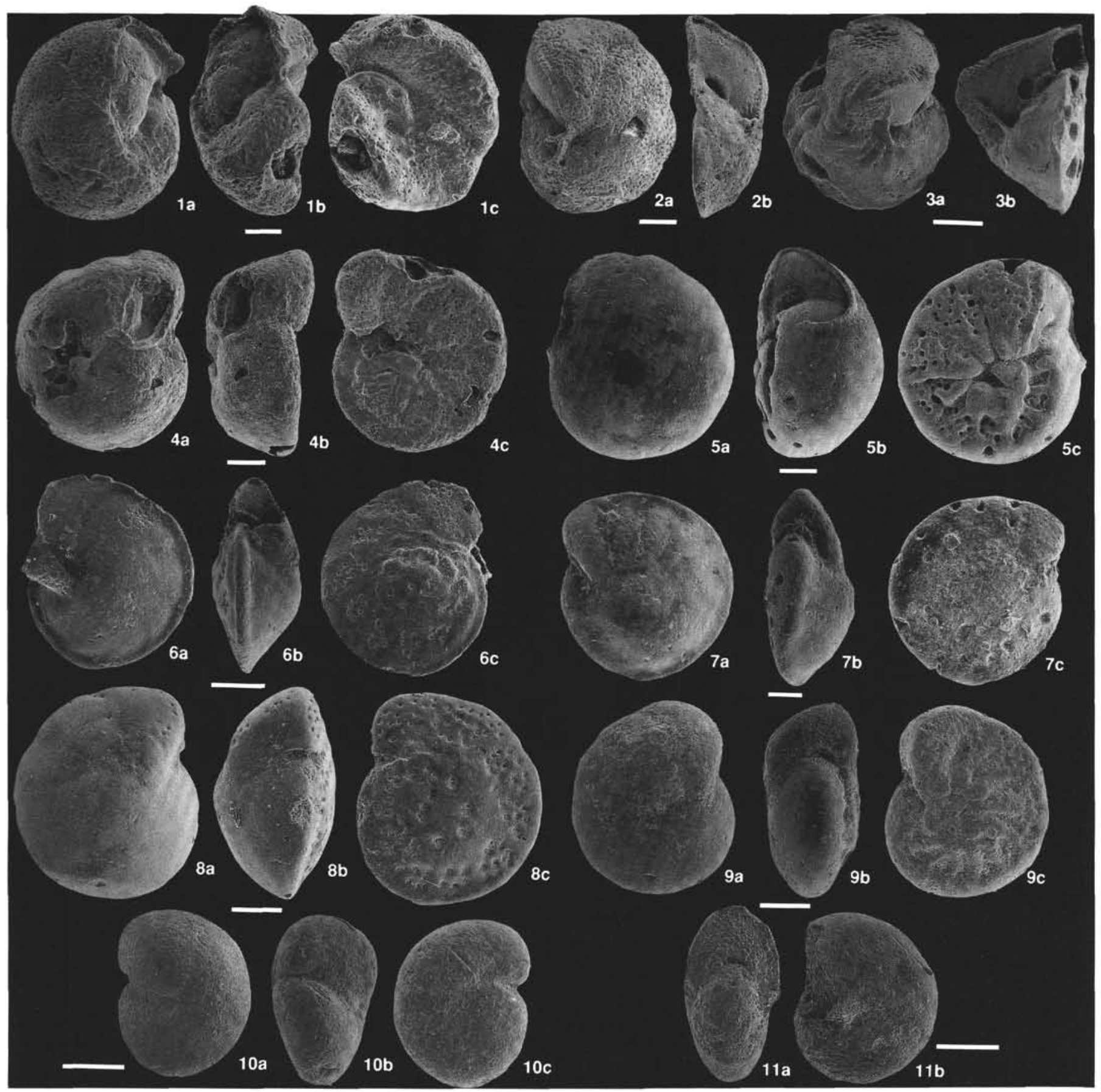

Plate 3. (Scale bar $=100 \mu \mathrm{m}$ ) 1a-c. Cibicides cf. ribbingi Brotzen. Sample 121-752B-17R-5, 66-69 cm. 2a-b. Cibicidina walli Bandy. Sample 121-752A-11H-5, 70-75 cm. 3a-b. Cibicidoides cf. laurisae (Mallory). Sample 121-752A-11H-5, 70-75 cm. 4a-c. Cibicidoides cf. grimsdalei (Nuttall). Sample 121-752A-20X-1, $70-75 \mathrm{~cm}$. 5a-c. Cibicidoides velascoensis (Cushman). Sample 121-752A-22X-1, 70-75 cm. 6a-c. Cibicidoides subspiratus (Nuttall). Sample 121-752A-13X-4, $62-67 \mathrm{~cm}$. 7a-c. Cibicidoides cf. pseudoperlucidus Bykova. Sample 121-752A-28X-5, 70-75 cm. 8a-c. Cibicidoides eocaenus (Gümbel). Sample 121-752A13X-1, 70-75 cm. 9a-c. Cibicidoides hyphalus (Fisher). Sample 121-752A-26X-1, 97-100 cm. 10a-c. Gyroidinoides planulatus (Cushman and Renz). Sample 121-752A-29X-1, 70-73 cm. 11a-b. Nonion havanensis Cushman and Bermúdez. Sample 121-752A-25X-1, 79-84 cm. 


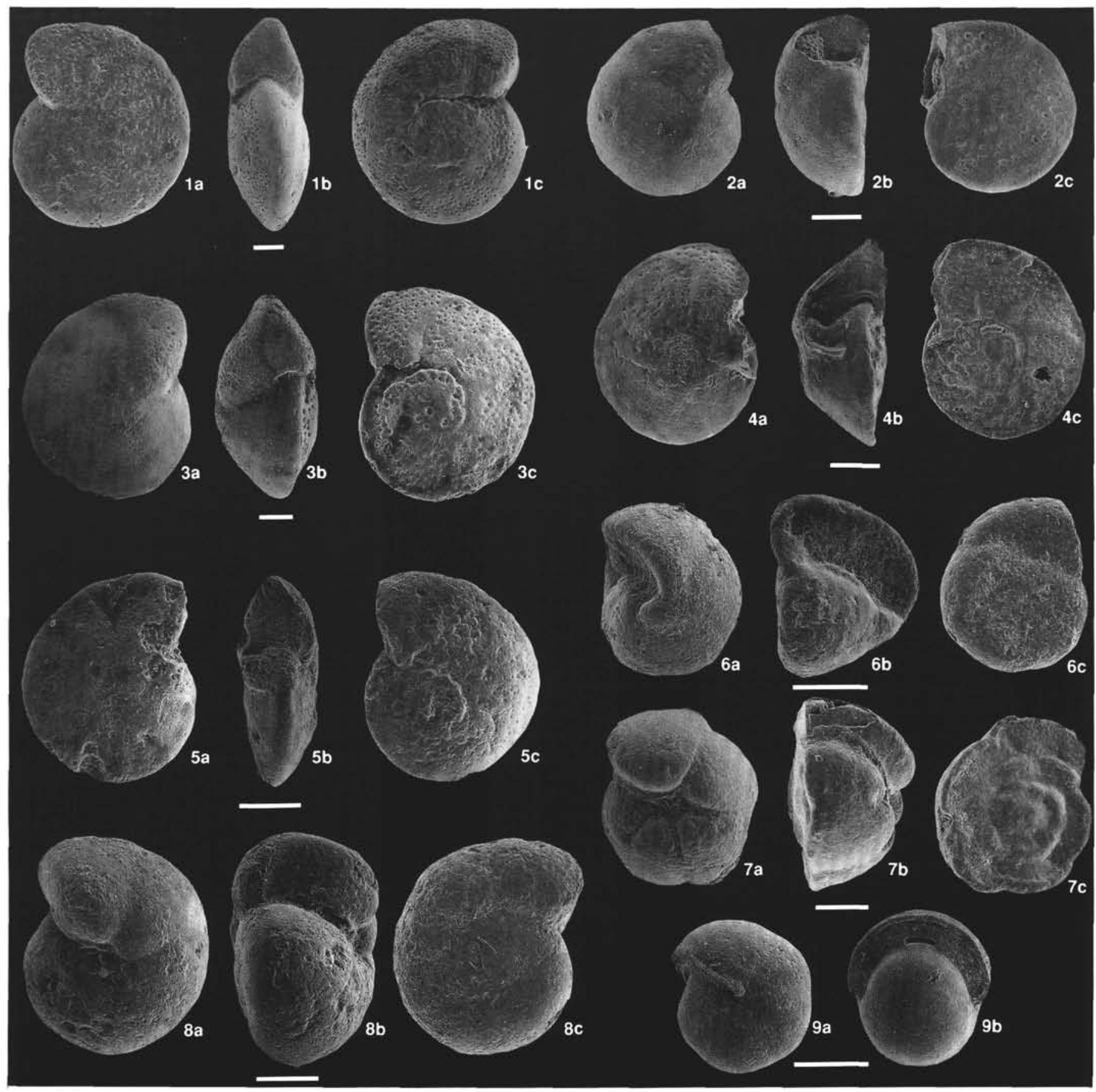

Plate 4. (Scale bar $=100 \mu \mathrm{m})$ 1a-c. Cibicidoides dayi (White). Sample 121-752B-14R-1, 69-72 cm. 2a-c. Cibididoides sp. 12. Sample 121-752A-18X-1, 71-75 $\mathrm{cm}$. 3a-c. Cibicidoides sp. 6. Sample 121-752A-18X-1, 71-75 cm. 4a-c. Cibicidoides sp. 5. Sample 121-752A-13X-4, 62-67 cm. 5a-c. Gavelinella sp. Sample 121-752B-7R-5, 76-78 cm. 6a-c. Gyroidinoides sp. 2. Sample 121-752B-7R-5, 76-78 cm. 7a-c. Gyroidinoides quadratus (Cushman and Church). Sample 121-752B-19R-3, 49-52 cm. 8a-c. Gyroidinoides globosus (Hagenow). Sample 121-752A-33X-3, 57-60 cm. 9a-b. Pullenia coryelli White. Sample $121-752 \mathrm{~A}-20 \mathrm{X}-1,70-75 \mathrm{~cm}$. 


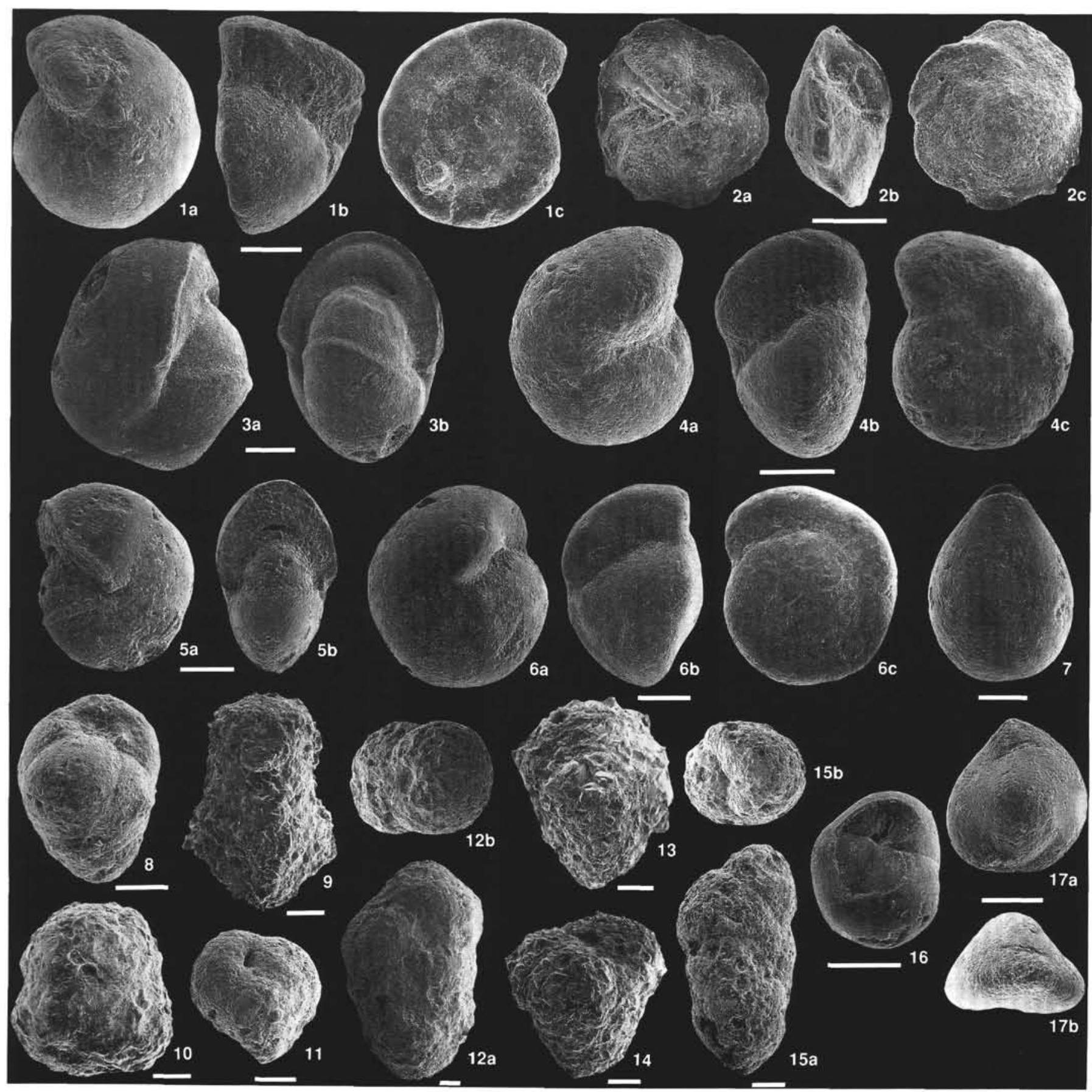

Plate 5. (Scale bar $=100 \mu \mathrm{m})$ 1a-c. Gyroidina noda Belford. Sample 121-752B-7R-1, 80-85 cm. 2a-c. Globorotalites conicus Carsey. Sample 121-752B-12R-3, 10-13 cm. 3a-b. Pullenia eocenica Cushman and Siegfus. Sample 121-752A-16X-1, 70-75 cm. 4a-c. Gyroidinoides cf. excertus (Belford). Sample 121-752B10R-4, 79-81 cm. 5a-b. Pullenia americana Cushman. Sample 121-752A-19X-1, 70-75 cm. 6a-c. Oridorsalis sp. 1. Sample 121-752A-29X-1, 70-73 cm. 7. Ellipsoidina ellipsoides Seguenza. Sample 121-752B-10R-1, 105-108 cm. 8. Gravelinella sp. Sample 121-752A-15X-5, 70-75 cm. 9. Tritaxia globulifera (ten Dam and Sigal). Sample 121-752A-26X-5, 97-100 cm. 10. Ammosphaeroidina sp. Sample 121-752A-32X-1, 70-75 cm. 11. Gaudryina pyramidata Cushman. Sample 121-752A-22X-1, 70-75 cm. 12a-b. Remesella variance (Glaesser). Sample 121-752B-8R-6,101-104 cm. 13. Tritaxia paleocenica Tjalsma and Lohman. Sample 121-752A-26X-1,97-100 cm. 14. Eggerella sp. Sample 121-752A-27X-1, 70-75 cm. 15a-b. Dorothia bulletta (Carsey). Sample 121-752B-14R-1, 69-72 $\mathrm{cm}$. 16. Globocassidulina globosa (Hantken). Sample 121-752A-15X-5, 112-115 cm. 17a-b. Guttulina cf. trigonula (Reuss). Sample 121-752B-7R-1, 82-85 cm. 